\title{
Relationships between the geographic distribution of phytophagous insects and different types of vegetation: A case study of the flea beetle genus Chaetocnema (Coleoptera: Chrysomelidae) in the Afrotropical region
}

\author{
Maurizio BIONDI, Fabrizia URBANI and PaOla D’ALESSANDRO \\ Department of Health, Life and Environmental Sciences, University of L'Aquila, 67100 Coppito-L'Aquila, Italy; \\ e-mails: maurizio.biondi@univaq.it; fabriziaurbani@yahoo.it; paola.dalessandro@univaq.it
}

Key words. Coleoptera, Chrysomelidae, Chaetocnema, chorotypes, cluster analysis, geographical range, flea beetles, Madagascar, Sub-Saharan Africa, vegetation types

\begin{abstract}
This study analyses the geographic distributions of 95 endemic and sub-endemic species of Chaetocnema (Coleoptera: Chrysomelidae) found in Sub-Saharan Africa and Madagascar, in order to compare and correlate their pattern of the geographic range (chorotype) and the distribution of terrestrial ecosystems in Africa and Madagascar. The data compiled for the species of Chaetocnema are based on records for 1639 collecting localities. Most of the species of Chaetocnema have restricted geographical ranges (67.3\%), whereas relatively few species $(11.6 \%)$ are very widely distributed. The latitudinal and longitudinal gradients in the numbers of species reveal that the highest levels of species richness occur in the Equatorial Belt and Southern Africa. Species of Chaetocnema in Sub-Saharan Africa have a clear preference for grassland and the wide-open environment associated with savannah. However, forest ecosystems are also important for numerous species, particularly in Madagascar. Several endemic species are associated with the Mediterranean vegetation in the southern part of West Africa. Species of Chaetocnema are generally associated with a limited number of vegetation types within the Afrotropical region. A cluster analysis based on calculating the squared Euclidean distance and using the WARD clustering method revealed a significant correlation between the chorotype and the vegetation types associated with each species. Finally, certain species of Chaetocnema that are characteristic of specific types of vegetation and/or indicators of biodiversity hotspots in Sub-Saharan Africa and Madagascar are highlighted.
\end{abstract}

\section{INTRODUCTION}

The ability to model the spatial distribution of species is of considerable importance in biogeography and conservation biology (Ferrier, 2002; Funk \& Richardson, 2002; Rushton et al., 2004; Elith et al., 2006) because the analysis of species-environment relationships have always been a central issue in ecology (Lawton, 1983; McCoy \& Bell, 1991; Tews et al., 2004).

The construction of databases using the Geographic Information System (GIS) for mapping and managing species distribution records and environmental data is relatively straightforward, and biological recording schemes routinely use GIS and/or relational database technologies to manage and maintain data resources. When the distribution and environmental data for species are integrated within a GIS environment, these data can be used to develop models for predicting the distribution of species (Franklin, 2009).

Distribution patterns of animals depend on several factors that may be ecological-environmental (recent or past), geographic, historical or related to an extinction-recolonisation event. Plant communities play a central role in influencing the distribution of phytophagous species.

The goal of this research is to interpret broad reliable presence-absence datasets for numerous species of Afrotropical Chaetocnema Stephens (Chrysomelidae: Galerucinae: Alticini), a genus of phytophagous flea beetles, in terms of the distribution of different types of African vegetation, primarily their divisions and formations, as identi- fied and described by Sayre et al. (2013). The leaf beetle genus Chaetocnema, includes over 400 described species, which occur in all zoogeographical regions (sensu Sclater, 1858). Approximately 120 species occur in the Palaearctic region (Löbl \& Smetana, 2010), 59 in the Nearctic region (White, 1996), 106 in the Neotropical region and approximately 100 in the Oriental and Australian regions (Konstantinov et al., 2011). Over 100 described species occur in the Afrotropical region (Biondi \& D'Alessandro, 2012).

Species of Chaetocnema generally inhabit moist environments and grassland, and are associated with plants belonging to several botanical families, particularly the Chenopodiaceae (currently included in the Amaranthaceae), Polygonaceae, Cyperaceae and Poaceae (Jolivet \& Hawkeswood, 1995).

The geographical distribution of plants and animals may be described in terms of their "chorotypes". A chorotype is a group of species whose distribution in space overlap more than expected by chance and is deduced from a comparative analysis of the geographical ranges of species, genera and higher taxa (Vigna Taglianti et al., 1992, 1999). It represents then a statistically significant group of coincident distribution areas, constituting reference biogeographic units (Olivero et al., 2011). Our research analyses the geographic distribution of 95 endemic and sub-endemic species of Chaetocnema that occur in Sub-Saharan Africa and Madagascar (Table 1) and compares and correlates their chorotypes as defined for the Afrotropical region by Biondi 
TABLE 1. Occurrence of endemic and sub-endemic species of Chaetocnema in the different vegetation divisions of Sub-Saharan Africa and Madagascar proposed by Sayre et al. (2013) (for abbreviations of the vegetation types see the legend of Fig. 1). Chorotypes: AEQ - Afro-Equatorial; AFT - Afrotropical; AIT - Afro-Intertropical; CAT - Central Afrotropical; EAF - Eastern Afrotropical; MAL - Malagasy; NAT - Northern Afrotropical; NEA - North-Eastern Afrotropical; NWA - North-Western Afrotropical; PAF - Pan-African; SAF - Southern African; SEA - South-East African; SWA - South-West Afrotropical.

Species

abyssinica Jacoby,1907
acutangola Weise,1910
aeneocyanea Laboissière, 1942
aluwala Bechyné, 1954
antennata Jacoby, 1897
audisiana Biondi, 2000
bamakoensis Bechyné, 1955
barkeri Jacoby, 1906
basipunctata Bechyné, 1964
bechuana Bechyné, 1959
bevinsi Bryant, 1928
bilunulata Demaison, 1902
brincki Bechyné, 1959)
cachani Biondi, 2001

cachani Biondi, 2001

capeneri Biondi \& D'Alessandro 2006

cerylonina Bechyné, 1960

cinctipennis Laboissière, 1941

coletta Bechyné, 1955

compressipes (Baly, 1876)

consobrina Weise, 1910
convexicollis (Boheman, 1859)
coronilla Bechyné, 1964

danielssoni Biondi \& D’Alessandro, 2006

darwini Bryant, 1928

desaegeri Scherer, 1962

dialloha Bechyné, 1955

dubreka Bechyne, 1955

frereensis Jacoby, 1899

ganganensis Bechyné, 1955

genia Bechyné, 1960

gregaria Weise, 1910

hygrophila Biondi, 2001

impressicollis Laboissière, 1942

kapirensis Biondi \& De Nardis, 2000

kibonotensis Weise, 1910
latipennis Pic, 1911

latipennis Pic, 1911

latipes Scherer, 1962

longicornis Jacoby, 1895

longicornis Jacoby, 1895

lopatini Biondi \& D' Alessandro, 2005

lualaba Bechyné, 1960

lucidipes Scherer, 1962
lufira Bechyné, 1960

madagascariensis Baly, 1877
malgascia Biondi, 2001

malgascia Biondi, 2001

maniemaensis Scherer, 1962

mapumalangaensis Biondi \& De Nardis, 2000 mariobiondii Biondi \& De Nardis, 2000

miloensis Bechyné, 1955
montana Bryant, 1928

mukana Bechyné, 1960

muva Bechyné, 1960

nahelia Bechyné, 1955

natalensis Baly, 1877

ndesei Laboissière, 1942

nigrosericea Bechyné, 1960

nigrosericea Bechyne,

nkolentangana Bechyné, 1955

obscura Laboissière, 1942

orophila Biondi, 2001

pastoria Bechyné, 1955

pauliani Bechyné 1964

phuthaditjhabensis Biondi \& De Nardis, 2000

pulla Chapuis, 1879

purpurea Jacoby, 1906

pusilla Laboissière, 1942

reprehensa Bechyné, 1960

rotundicollis Scherer, 1962

rutovuensis Bechyné, 195

schlaeflii (Stierlin, 1866)

semiregulata Jacoby, 1897

similis Weise, 1910

subaterrima Jacoby, 1900

subquadrata Jacoby, 1897

sudafricana Biondi \& D'Alessandro, 2006

suturalis Bryant, 1948

tablensis Bryant, 1928

tarsalis Wollaston, 1860

tongaatensis (Bechyné, 1959)

tuckeri Biondi \& D’Alessandro, 2006

turneri Bryant, 1928

vadoni Bechyné, 1948
vanschuytbroecki Biondi \& D'Alessandro, 2007

varicolor Jacoby, 1899

wollastoni Baly, 1877
zulu Biondi \& De Nardis, 2000

zumpti Bechyné, 1954
Chorotype

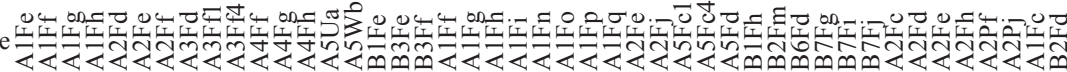

EAF $\quad \begin{array}{lllllllllllllllllllllllllllllllllllllllllllll}0 & 0 & 1 & 0 & 1 & 0 & 1 & 1 & 0 & 1 & 0 & 0 & 0 & 0 & 1 & 0 & 0 & 0 & 1 & 1 & 1 & 1 & 1 & 1 & 0 & 0 & 1 & 0 & 0 & 0 & 0 & 0 & 1 & 0 & 0 & 0 & 0 & 0 & 0 & 1 & 0 & 0 & 0 & 0 & 1\end{array}$

\begin{tabular}{lllllllllllllllllllllllllllllllllllllllllllllllll}
$\mathrm{CAT}$ & 0 & 0 & 0 & 0 & 0 & 0 & 0 & 0 & 0 & 0 & 0 & 0 & 0 & 0 & 0 & 0 & 0 & 0 & 0 & 1 & 0 & 0 & 0 & 1 & 0 & 0 & 0 & 0 & 0 & 0 & 0 & 0 & 0 & 0 & 0 & 0 & 0 & 0 & 0 & 1 & 0 & 0 & 0 & 0 & 0 \\
\hline
\end{tabular}

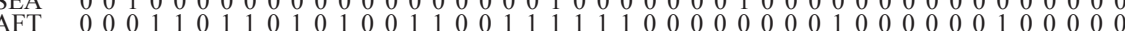

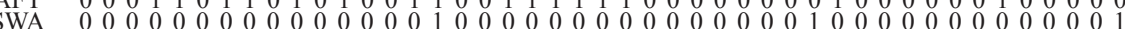

$\begin{array}{llllllllllllllllllllllllllllllllllllllllllllllll}\mathrm{SWA} & 0 & 0 & 0 & 0 & 0 & 0 & 0 & 0 & 0 & 0 & 0 & 0 & 0 & 0 & 0 & 1 & 0 & 0 & 0 & 0 & 0 & 0 & 0 & 0 & 0 & 0 & 0 & 0 & 0 & 0 & 0 & 1 & 0 & 0 & 0 & 0 & 0 & 0 & 0 & 0 & 0 & 0 & 0 & 0 & 1 \\ \text { AFT } & 0 & 0 & 0 & 0 & 1 & 1 & 0 & 0 & 0 & 1 & 0 & 0 & 0 & 1 & 1 & 0 & 0 & 0 & 1 & 1 & 0 & 1 & 1 & 1 & 1 & 0 & 0 & 0 & 0 & 0 & 0 & 0 & 0 & 0 & 0 & 1 & 0 & 0 & 0 & 1 & 0 & 0 & 0 & 0 & 0\end{array}$

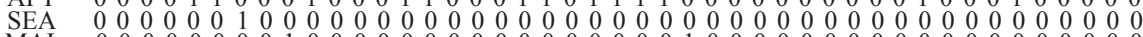

MAL $\quad \begin{array}{llllllllllllllllllllllllllllllllllllllllllllllllllll}0 & 0 & 0 & 0 & 0 & 0 & 0 & 0 & 1 & 0 & 0 & 0 & 0 & 0 & 0 & 0 & 0 & 0 & 0 & 0 & 0 & 0 & 0 & 0 & 0 & 1 & 0 & 0 & 0 & 0 & 0 & 0 & 0 & 0 & 0 & 0 & 0 & 0 & 0 & 0 & 0 & 0 & 0 & 0 & 0\end{array}$

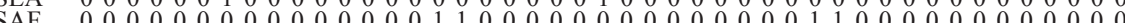

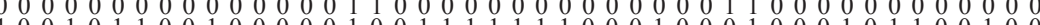

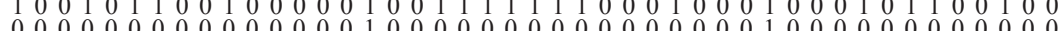

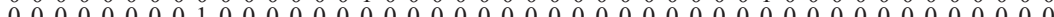

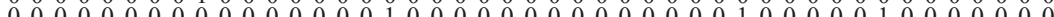

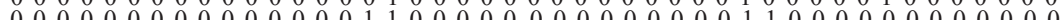

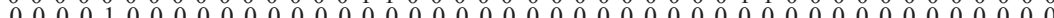

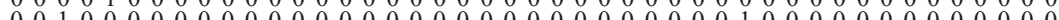

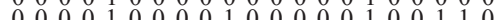

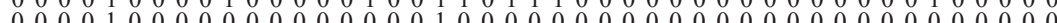

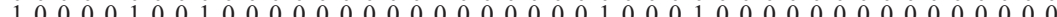

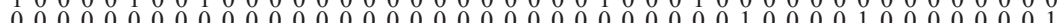

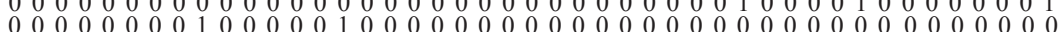

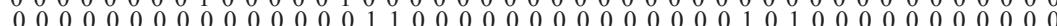
$\begin{array}{lllllllllllllllllllllllllllllllllllllllllllllllll}0 & 0 & 0 & 0 & 0 & 0 & 0 & 0 & 0 & 0 & 0 & 0 & 0 & 0 & 0 & 1 & 1 & 0 & 0 & 0 & 0 & 0 & 0 & 0 & 0 & 0 & 0 & 0 & 0 & 0 & 0 & 1 & 0 & 1 & 0 & 0 & 0 & 0 & 0 & 0 & 0 & 0 & 0 & 0 & 0 \\ 0 & 0 & 1 & 0 & 0 & 0 & 0 & 0 & 0 & 0 & 0 & 0 & 0 & 0 & 0 & 1 & 1 & 1 & 0 & 0 & 0 & 0 & 0 & 0 & 0 & 0 & 0\end{array}$

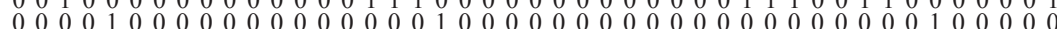
00000 $\begin{array}{lllllllllllllllllllllllllllllllllllllllllllllll}0 & 0 & 0 & 0 & 0 & 1 & 0 & 0 & 0 & 0 & 0 & 0 & 0 & 0 & 0 & 0 & 0 & 0 & 0 & 0 & 0 & 0 & 0 & 0 & 0 & 0 & 0 & 0 & 0 & 0 & 0 & 0 & 0 & 0 & 0 & 0 & 0 & 0 & 0 & 0 & 0 & 0 & 0 & 0 & 0 & 0\end{array}$

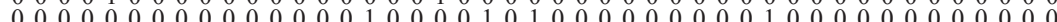

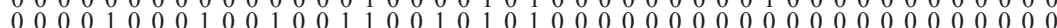

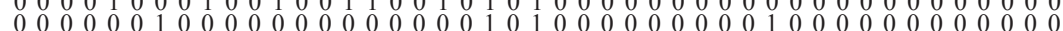

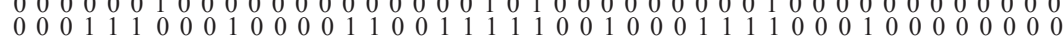
$\begin{array}{lllllllllllllllllllllllllllllllllllllllllllllllllllllll}0 & 0 & 0 & 0 & 0 & 0 & 0 & 0 & 0 & 1 & 0 & 0 & 0 & 0 & 0 & 0 & 0 & 0 & 0 & 0 & 1 & 0 & 1 & 0 & 0 & 0 & 0 & 0 & 0 & 0 & 0 & 0 & 0 & 0 & 0 & 0 & 0 & 0 & 0 & 0 & 0 & 0 & 0 & 0 & 0\end{array}$

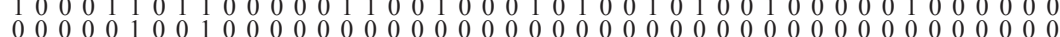

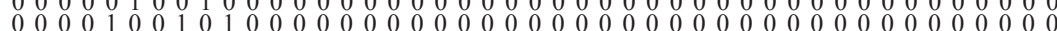

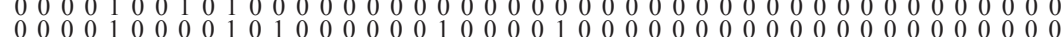
$\begin{array}{llllllllllllllllllllllllllllllllllllllllllllllllllllll}0 & 0 & 0 & 0 & 0 & 0 & 0 & 0 & 0 & 0 & 0 & 0 & 0 & 0 & 0 & 0 & 0 & 0 & 0 & 0 & 0 & 0 & 1 & 0 & 0 & 0 & 0 & 0 & 0 & 0 & 0 & 0 & 0 & 0 & 0 & 0 & 0 & 0 & 0 & 0 & 0 & 0 & 0 & 0 & 0\end{array}$

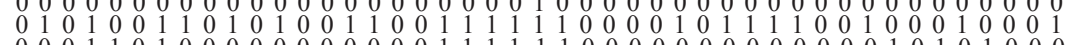

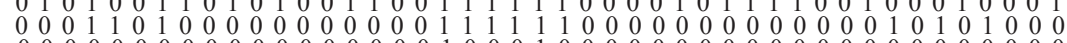
$\begin{array}{lllllllllllllllllllllllllllllllllllllllllllllll}0 & 0 & 0 & 0 & 0 & 0 & 0 & 0 & 0 & 0 & 0 & 0 & 0 & 0 & 0 & 0 & 0 & 0 & 1 & 0 & 0 & 0 & 1 & 0 & 0 & 0 & 0 & 0 & 0 & 0 & 0 & 0 & 0 & 0 & 0 & 0 & 0 & 0 & 0 & 0 & 0 & 0 & 0 & 0 & 0\end{array}$ $\begin{array}{llllllllllllllllllllllllllllllllllllllllllllllllllllllllllllllllllll}0 & 1 & 0 & 1 & 1 & 0 & 1 & 0 & 0 & 0 & 0 & 0 & 1 & 1 & 1 & 1 & 0 & 0 & 1 & 1 & 1 & 1 & 1 & 1 & 0 & 0 & 0 & 0 & 1 & 0 & 1 & 1 & 1 & 0 & 0 & 1 & 1 & 0 & 0 & 0 & 0 & 1 & 0 & 0 & 0\end{array}$ $\begin{array}{llllllllllllllllllllllllllllllllllllllllllllllllll}0 & 0 & 0 & 0 & 0 & 0 & 0 & 0 & 0 & 0 & 0 & 0 & 0 & 0 & 0 & 1 & 0 & 0 & 0 & 0 & 0 & 0 & 0 & 0 & 0 & 0 & 0 & 0 & 0 & 0 & 0 & 0 & 1 & 0 & 0 & 0 & 0 & 0 & 0 & 0 & 0 & 0 & 0 & 0 & 0\end{array}$ $\begin{array}{llllllllllllllllllllllllllllllllllllllllllllll}0 & 0 & 0 & 0 & 0 & 0 & 0 & 0 & 0 & 0 & 0 & 0 & 0 & 0 & 0 & 0 & 0 & 0 & 1 & 0 & 1 & 0 & 1 & 0 & 0 & 0 & 0 & 0 & 0 & 0 & 0 & 0 & 0 & 0 & 0 & 0 & 0 & 0 & 0 & 0 & 0 & 0 & 0 & 0 & 0\end{array}$ $\begin{array}{llllllllllllllllllllllllllllllllllllllllllllll}0 & 0 & 0 & 0 & 1 & 0 & 0 & 0 & 0 & 1 & 0 & 0 & 0 & 0 & 0 & 0 & 0 & 0 & 1 & 0 & 1 & 0 & 0 & 0 & 0 & 0 & 0 & 0 & 0 & 0 & 0 & 0 & 0 & 0 & 0 & 0 & 0 & 0 & 0 & 0 & 0 & 0 & 0 & 0 & 0 \\ 0 & 0 & 0 & 0 & 1 & 0 & 0 & 0 & 0 & 0 & 0 & 0 & 0 & 0 & 0 & 0 & 0 & 0 & 0 & 0 & 1 & 0 & 1 & 0 & 0 & 0 & 0 & 0 & 0 & 0 & 0 & 0 & 1 & 0 & 0 & 0 & 0 & 0 & 0 & 0 & 0 & 0 & 0 & 0 & 0\end{array}$ $\begin{array}{lllllllllllllllllllllllllllllllllllllllllllllllll}0 & 0 & 0 & 0 & 1 & 0 & 1 & 0 & 0 & 0 & 0 & 1 & 0 & 0 & 0 & 0 & 0 & 0 & 1 & 0 & 0 & 1 & 1 & 0 & 0 & 0 & 0 & 0 & 0 & 0 & 0 & 0 & 0 & 0 & 0 & 0 & 0 & 0 & 0 & 1 & 0 & 0 & 0 & 0 & 0\end{array}$ $\begin{array}{llllllllllllllllllllllllllllllllllllllllllllllllllllll}0 & 0 & 0 & 0 & 1 & 0 & 0 & 0 & 0 & 0 & 0 & 0 & 0 & 0 & 0 & 0 & 0 & 0 & 0 & 0 & 1 & 0 & 1 & 0 & 0 & 0 & 0 & 0 & 1 & 0 & 0 & 0 & 0 & 0 & 0 & 0 & 0 & 0 & 0 & 0 & 0 & 0 & 0 & 0 & 0\end{array}$ $\begin{array}{lllllllllllllllllllllllllllllllllllllllllllllll}0 & 0 & 0 & 0 & 0 & 0 & 0 & 0 & 0 & 0 & 0 & 0 & 0 & 0 & 0 & 0 & 0 & 0 & 0 & 0 & 0 & 0 & 0 & 0 & 0 & 0 & 0 & 0 & 0 & 1 & 0 & 0 & 0 & 0 & 0 & 0 & 0 & 0 & 0 & 0 & 0 & 0 & 0 & 0 & 0\end{array}$ $\begin{array}{lllllllllllllllllllllllllllllllllllllllllllllll}0 & 0 & 0 & 0 & 0 & 1 & 0 & 0 & 0 & 0 & 0 & 0 & 0 & 0 & 0 & 0 & 0 & 0 & 0 & 0 & 0 & 0 & 0 & 0 & 1 & 0 & 0 & 1 & 0 & 0 & 0 & 0 & 0 & 0 & 0 & 0 & 0 & 0 & 0 & 0 & 0 & 0 & 0 & 0 & 0\end{array}$

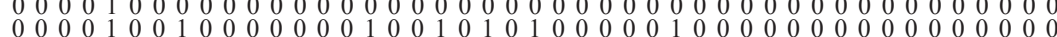
$\begin{array}{lllllllllllllllllllllllllllllllllllllllllllllllllll}0 & 0 & 0 & 0 & 0 & 0 & 0 & 0 & 0 & 0 & 0 & 0 & 0 & 0 & 0 & 0 & 0 & 0 & 0 & 0 & 0 & 0 & 0 & 0 & 0 & 0 & 0 & 0 & 0 & 0 & 0 & 0 & 1 & 0 & 0 & 0 & 0 & 0 & 0 & 0 & 0 & 0 & 0 & 0 & 0\end{array}$ $\begin{array}{llllllllllllllllllllllllllllllllllllllllllllll}0 & 0 & 0 & 0 & 0 & 0 & 0 & 0 & 0 & 0 & 0 & 0 & 0 & 0 & 0 & 1 & 0 & 0 & 0 & 0 & 0 & 0 & 0 & 0 & 0 & 0 & 0 & 0 & 0 & 0 & 0 & 0 & 0 & 0 & 0 & 0 & 0 & 0 & 0 & 0 & 0 & 0 & 0 & 0 & 0\end{array}$ $\begin{array}{llllllllllllllllllllllllllllllllllllllllllllll}0 & 0 & 0 & 0 & 1 & 0 & 0 & 1 & 0 & 1 & 0 & 0 & 0 & 0 & 0 & 0 & 0 & 0 & 1 & 0 & 0 & 0 & 1 & 1 & 0 & 0 & 1 & 0 & 0 & 0 & 0 & 0 & 0 & 0 & 0 & 1 & 0 & 0 & 0 & 1 & 0 & 0 & 0 & 0 & 0 \\ 0 & 0 & 0 & 0 & 0 & 0 & 0 & 0 & 0 & 1 & 0 & 0 & 0 & 0 & 0 & 1 & 1 & 0 & 0 & 1 & 1 & 1 & 1 & 1 & 0 & 0 & 0 & 0 & 1 & 0 & 1 & 1 & 1 & 0 & 0 & 1 & 1 & 0 & 0 & 0 & 1 & 0 & 0 & 0 & 0 & 0\end{array}$ $\begin{array}{llllllllllllllllllllllllllllllllllllllllllllll}0 & 0 & 0 & 0 & 0 & 0 & 0 & 0 & 0 & 0 & 0 & 0 & 0 & 0 & 0 & 0 & 0 & 0 & 0 & 0 & 0 & 0 & 1 & 0 & 0 & 0 & 0 & 0 & 0 & 0 & 0 & 0 & 0 & 0 & 0 & 0 & 0 & 0 & 0 & 0 & 0 & 0 & 0 & 0 & 0\end{array}$ $\begin{array}{llllllllllllllllllllllllllll}0 & 0 & 0 & 0 & 1 & 0 & 0 & 0 & 0 & 0 & 0 & 0 & 0 & 1 & 0 & 0 & 0 & 0 & 0 & 0 & 0\end{array}$ $\begin{array}{llllllllllllllllllllllllllllllllllllllllllllll}0 & 0 & 1 & 1 & 0 & 0 & 1 & 0 & 0 & 1 & 0 & 0 & 0 & 0 & 0 & 1 & 0 & 1 & 0 & 0 & 1 & 0 & 1 & 0 & 0 & 0 & 0 & 0 & 1 & 0 & 0 & 1 & 1 & 0 & 1 & 0 & 1 & 0 & 0 & 0 & 0 & 0 & 0 & 1 & 1 \\ 0 & 0 & 0 & 0 & 0 & 0 & 0 & 0 & 0 & 1 & 0 & 0 & 0 & 0 & 0 & 0 & 0 & 0 & 1 & 1 & 1 & 1 & 1 & 1 & 0 & 0 & 0 & 0 & 0 & 0 & 0 & 0 & 1 & 0 & 0 & 0 & 0 & 0 & 0 & 0 & 0 & 0 & 0 & 0 & 0 & 0\end{array}$ $\begin{array}{lllllllllllllllllllllllllllllllllllllllllllllll}0 & 0 & 0 & 1 & 1 & 0 & 0 & 1 & 0 & 0 & 0 & 1 & 0 & 0 & 0 & 1 & 0 & 0 & 1 & 1 & 1 & 1 & 1 & 1 & 0 & 0 & 0 & 0 & 1 & 0 & 0 & 0 & 1 & 0 & 0 & 0 & 0 & 0 & 0 & 1 & 0 & 0 & 0 & 0 & 0\end{array}$

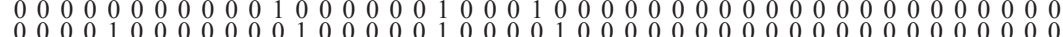
$\begin{array}{llllllllllllllllllllllllllll}0 & 0 & 0 & 0 & 1 & 0 & 0 & 0 & 0 & 0 & 0 & 0 & 1 & 0 & 0 & 0 & 0 & 0 & 1 & 0 & 0 & 0 & 0 & 1 & 0 & 0 \\ 0 & 0 & 0 & 0 & 1 & 0 & 0 & 0 & 0 & 0 & 0 & 0 & 0 & 0 & 0 & 0 & 0\end{array}$

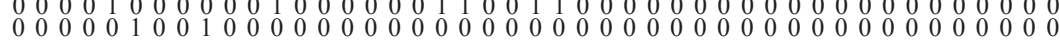
$\begin{array}{lllllllllllllllllllllllllllllllllllllllllllllll}0 & 1 & 0 & 0 & 1 & 0 & 0 & 1 & 0 & 1 & 0 & 1 & 0 & 1 & 0 & 0 & 0 & 0 & 1 & 0 & 0 & 1 & 0 & 1 & 0 & 0 & 0 & 0 & 0 & 0 & 0 & 0 & 0 & 0 & 0 & 0 & 0 & 0 & 0 & 1 & 0 & 0 & 0 & 0 & 0\end{array}$

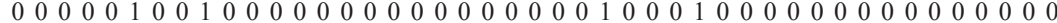
$\begin{array}{lllllllllllllllllllllllllllllllllllllllllllllll}0 & 0 & 0 & 0 & 0 & 0 & 1 & 0 & 0 & 0 & 0 & 0 & 0 & 0 & 0 & 0 & 0 & 0 & 0 & 0 & 0 & 0 & 0 & 0 & 0 & 0 & 0 & 0 & 0 & 0 & 0 & 0 & 1 & 0 & 0 & 0 & 0 & 0 & 0 & 0 & 0 & 0 & 0 & 0 & 0\end{array}$

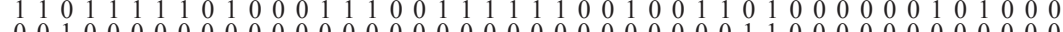
$\begin{array}{llllllllllllllllllllllllllllllllllllllllllllllllllllllll}0 & 0 & 1 & 0 & 0 & 0 & 0 & 0 & 0 & 0 & 0 & 0 & 0 & 0 & 0 & 0 & 0 & 0 & 0 & 0 & 0 & 0 & 0 & 0 & 0 & 0 & 0 & 0 & 0 & 0 & 0 & 1 & 1 & 0 & 0 & 0 & 0 & 0 & 0 & 0 & 0 & 0 & 0 & 0 & 0\end{array}$ $\begin{array}{llllllllllllllllllllllllllllllllllllllllllllll}0 & 1 & 0 & 1 & 0 & 0 & 0 & 0 & 0 & 1 & 0 & 0 & 0 & 0 & 0 & 0 & 0 & 0 & 1 & 0 & 1 & 0 & 1 & 1 & 0 & 0 & 1 & 0 & 1 & 0 & 0 & 0 & 0 & 0 & 0 & 0 & 0 & 0 & 0 & 1 & 1 & 0 & 0 & 0 & 0\end{array}$

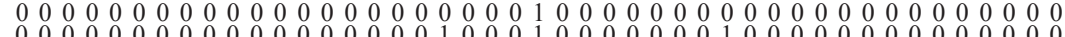
$\begin{array}{lllllllllllllllllllllllllllllllllllllllllllllll}0 & 0 & 0 & 0 & 0 & 0 & 0 & 0 & 0 & 0 & 0 & 0 & 0 & 0 & 0 & 0 & 0 & 0 & 1 & 0 & 0 & 0 & 1 & 0 & 0 & 0 & 0 & 0 & 0 & 0 & 1 & 0 & 0 & 0 & 0 & 0 & 0 & 0 & 0 & 0 & 0 & 0 & 0 & 0 & 0\end{array}$ $\begin{array}{llllllllllllllllllllllllllllllllllllllllllllllllllllll}0 & 0 & 0 & 0 & 0 & 0 & 0 & 1 & 0 & 0 & 0 & 0 & 0 & 0 & 0 & 0 & 0 & 0 & 0 & 0 & 0 & 0 & 0 & 0 & 0 & 0 & 0 & 0 & 0 & 0 & 0 & 0 & 0 & 0 & 0 & 0 & 0 & 0 & 0 & 0 & 0 & 0 & 0 & 0 & 0\end{array}$

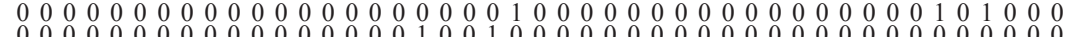
$\begin{array}{lllllllllllllllllllllllllllllllllllllllllllllll}0 & 0 & 0 & 0 & 0 & 0 & 0 & 0 & 0 & 0 & 0 & 0 & 0 & 0 & 0 & 0 & 0 & 1 & 0 & 0 & 1 & 0 & 0 & 0 & 0 & 0 & 0 & 0 & 0 & 0 & 0 & 0 & 0 & 0 & 0 & 0 & 0 & 0 & 0 & 0 & 0 & 0 & 0 & 0 & 0\end{array}$ $\begin{array}{lllllllllllllllllllllllllllllllllllllllllllllllll}1 & 0 & 0 & 0 & 0 & 1 & 0 & 0 & 0 & 0 & 0 & 0 & 0 & 0 & 1 & 0 & 0 & 0 & 0 & 0 & 0 & 0 & 0 & 0 & 0 & 0 & 0 & 0 & 0 & 0 & 0 & 0 & 0 & 0 & 0 & 0 & 0 & 0 & 0 & 0 & 0 & 0 & 0 & 0 & 0\end{array}$

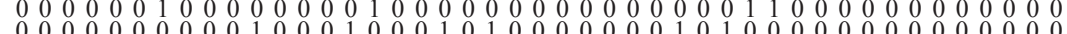
$\begin{array}{llllllllllllllllllllllllllllllllllllllllllllllllllll}0 & 0 & 0 & 0 & 0 & 0 & 0 & 0 & 0 & 0 & 1 & 0 & 0 & 0 & 1 & 0 & 0 & 0 & 1 & 0 & 1 & 0 & 0 & 0 & 0 & 0 & 0 & 0 & 1 & 0 & 1 & 0 & 0 & 0 & 0 & 0 & 0 & 0 & 0 & 0 & 0 & 0 & 0 & 0 & 0\end{array}$

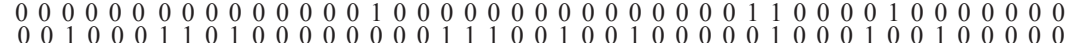
$\begin{array}{llllllllllllllllllllllllllllllllllllllllllllll}0 & 0 & 1 & 0 & 0 & 0 & 1 & 1 & 0 & 1 & 0 & 0 & 0 & 0 & 0 & 0 & 0 & 0 & 1 & 1 & 1 & 0 & 0 & 1 & 0 & 0 & 1 & 0 & 0 & 0 & 0 & 0 & 1 & 0 & 0 & 0 & 1 & 0 & 0 & 1 & 0 & 0 & 0 & 0 & 0 \\ 0 & 0 & 0 & 0 & 0 & 0 & 0 & 0 & 0 & 0 & 0 & 0 & 0 & 0 & 0 & 1 & 1 & 0 & 0 & 0 & 0 & 0 & 0 & 0 & 0 & 0 & 0 & 0 & 0 & 0 & 0 & 1 & 0 & 0 & 0 & 0 & 0 & 0 & 0 & 0 & 0 & 0 & 0 & 0 & 0\end{array}$ $\begin{array}{lllllllllllllllllllllllllllllllllllllllllllllllll}0 & 0 & 0 & 0 & 0 & 0 & 0 & 0 & 0 & 0 & 0 & 0 & 0 & 0 & 0 & 1 & 1 & 0 & 0 & 0 & 0 & 0 & 0 & 0 & 0 & 0 & 0 & 0 & 0 & 0 & 0 & 1 & 0 & 0 & 0 & 0 & 0 & 0 & 0 & 0 & 0 & 0 & 0 & 0 & 0\end{array}$

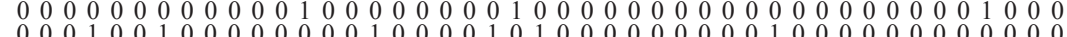
$\begin{array}{llllllllllllllllllllllllllllllllllllllllllllll}0 & 0 & 0 & 1 & 0 & 0 & 1 & 0 & 0 & 0 & 0 & 0 & 0 & 0 & 0 & 1 & 0 & 0 & 0 & 0 & 1 & 0 & 1 & 0 & 0 & 0 & 0 & 0 & 0 & 0 & 0 & 0 & 1 & 0 & 0 & 0 & 0 & 0 & 0 & 0 & 0 & 0 & 0 & 0 & 0 \\ 0 & 0 & 0 & 0 & 0 & 0 & 0 & 0 & 0 & 0 & 0 & 0 & 0 & 0 & 0 & 0 & 0 & 0 & 0 & 1 & 1 & 0 & 0 & 0 & 0 & 0 & 0 & 0 & 0 & 0 & 0 & 0 & 0 & 0 & 0 & 0 & 1 & 1 & 0 & 0 & 1 & 0 & 0 & 0 & 0\end{array}$

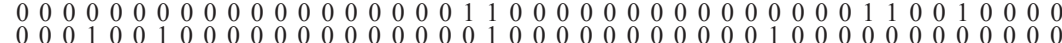

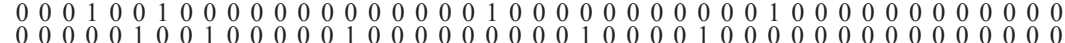

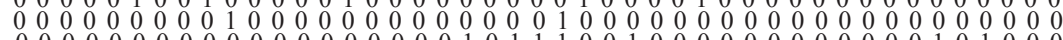

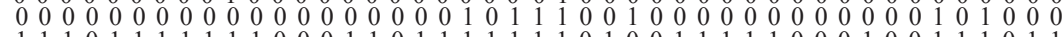
$\begin{array}{llllllllllllllllllllllllllllllllllllllllllllll}1 & 1 & 1 & 0 & 1 & 1 & 1 & 1 & 1 & 1 & 1 & 0 & 0 & 0 & 1 & 1 & 0 & 1 & 1 & 1 & 1 & 1 & 1 & 1 & 0 & 1 & 0 & 0 & 1 & 1 & 1 & 1 & 1 & 0 & 0 & 0 & 1 & 0 & 0 & 1 & 1 & 1 & 0 & 1 & 1\end{array}$ \begin{tabular}{lllllllllllllllllllllllllllllllllllllllllllllllll}
0 & 0 & 0 & 0 & 0 & 0 & 0 & 0 & 0 & 0 & 0 & 0 & 0 & 0 & 0 & 1 & 0 & 0 & 0 & 0 & 0 & 0 & 0 & 0 & 0 & 0 & 0 & 0 & 0 & 0 & 0 & 0 & 1 & 0 & 0 & 0 & 0 & 0 & 0 & 0 & 0 & 0 & 0 & 0 & 0 \\
0 & 0 & 0 & 0 & 1 & 0 & 0 & 1 & 0 & 1 & 0 & 1 & 0 & 0 & 0 & 1 & 0 & 0 & 1 & 0 & 1 & 0 & 1 & 0 & 0 & 0 & 0 & 0 & 0 & 0 & 0 & 0 & 1 & 0 & 0 & 0 & 0 & 0 & 0 & 1 & 0 & 0 & 0 & 0 & 0 \\
\hline
\end{tabular} 
\& D'Alessandro (2006a) with the distribution of terrestrial ecosystems in Africa and Madagascar as defined by Sayre et al. (2013). The results are also discussed in terms of their potential use in aiding conservation biology in the Afrotropical region.

\section{MATERIAL AND METHODS}

\section{Study area}

The research area is delimited in Fig. 1 and includes Madagascar and continental Sub-Saharan Africa, which is situated in the region that lies between $17.5^{\circ} \mathrm{W}$ and $52^{\circ} \mathrm{E}$ longitude and $20^{\circ} \mathrm{N}$ and $35^{\circ} \mathrm{S}$ latitude. Distribution maps were constructed using ESRI ArcGIS 10.0 software.

\section{Database of vegetation types}

Vegetation types considered in this study are those of Sayre et al. (2013), who developed a hierarchical classification of the terrestrial ecosystems in Sub-Saharan Africa and Madagascar based on 163 vegetation macro-groups, 53 divisions, 17 formations, seven subclasses and four classes. Vegetation divisions, formations and subclasses were the types primarily used in this research (Figs 1-2). Macro-groups were only considered in two cases: (a) Eastern Madagascar Montane Forest (1.A.3.Ff.1) in Madagascar vs Moist Evergreen Montane Forest (1.A.3.Ff.1.4) in southern Africa; (b) African Tropical Freshwater Marsh (Dembos) (2.A.5.Fc.1) in Madagascar vs African Temperate Moorland (2.A.5.Fc.4) in eastern Africa. This conservative approach was selected to avoid extensive fragmentation of faunistic data (Martín \& Gurrea, 1999), because although present assumptions about the distribution of species of Chaetocnema in the Afrotropical region are robust, they remain far from complete (Biondi \& D'Alessandro, 2006a). Vegetation maps were plotted and analyzed using ESRI ArcGIS 10.0 software.

\section{Chaetocnema database}

Our database of endemic and sub-endemic species of Chaetocnema occurring in the Afrotropical region (Table 1) included in the statistical analyses consisted of the following: (a) data collected from peer-reviewed literature, with a specific focus on the work of Bechyné (1948, 1954, 1955a, b, 1959a, b, 1960a, b, 1964, 1968), Biondi (2001, 2002a, b), Biondi \& D'Alessandro (2005, 2006a, b, 2008), Biondi \& De Nardis (2000), Bryant (1926, 1928 , 1948, 1959a, b, 1960) and Scherer (1959, 1961a,b, 1962a, b, 1963, 1969, 1970, 1972, 1978); (b) data from all major collections of African insects, primarily those located in the BMNH, IRSNB, MNHN, MSNG, MZLU, NHMB, NHRS, NMPC, RMCA, SAMC, SANC, TMSA, ZMHB and ZSM. The data for all the species of Chaetocnema considered are based on material from 1,639 localities in Sub-Saharan Africa and Madagascar. Geographic coordinates were derived from label data or obtained and/or corrected using Google Earth ver. 7.1.2.2041. The terminology and typology used for the chorotypes (Fig. 3) in the Afrotropical region follow Biondi \& D'Alessandro (2006a).

\section{Statistical analysis}

A cluster analysis using presence-absence data of the vegetation types for each species considered was performed to find "ecologically similar" species-groups of Chaetocnema (Table 1). The analysis was conducted by calculating the Squared Euclidean Distance and using of the WARD Clustering Method (Ward, 1963; Kent, 2006). Notwithstanding that the Euclidean distance is considered to be inappropriate for analyzing the composition of communities using abundance-based data (Legendre \& De Cáceres, 2013), the squared Euclidean distance is suitable for binary data because it becomes equivalent to the Hamming distance (Lourenço et al., 2004). Statistical analyses were performed and graphics produced using the NCSS version 9.0.7 package for Windows (Hintze, 2013).

\section{Abbreviations used}

Depositories. BMNH: The Natural History Museum, London, United Kingdom; IRSNB: Institut Royal des Sciences Naturelles de Belgique, Brussels, Belgium; MNHN: Muséum National d'Histoire Naturelle, Paris, France; MSNG: Museo Civico di Storia Naturale "Giacomo Doria", Genova, Italy; MZLU: Lund University, Sweden; NHMB: Naturhistorisches Museum, Basel, Switzerland; NHRS: Naturhistoriska Riksmuseet, Stockholm, Sweden; NMPC: Entomologické oddělení Národního muzea, Praha-Kunratice, Czech Republic; RMCA: Musée Royal de l'Afrique Centrale, Tervuren, Belgium; SAMC: Iziko South African Museum, Cape Town, South Africa; SANC: South African National Collection, ARC-Plant Protection Research Institute, Pretoria, South Africa; TMSA: Ditsong National Museum of Natural History (formerly Transvaal Museum), Pretoria, South Africa; ZMHB: Museum für Naturkunde der Humboldt-Universität, Berlin, Germany; ZSM: Zoologische Sammlung des Bayerischen Staates, München, Germany.

Chorotypes. AEQ: Afro-Equatorial; AFT: Afrotropical; AIT: Afro-Intertropical; CAT: Central Afrotropical; EAF: Eastern Afrotropical; MAL: Malagasy; NAT: Northern Afrotropical; NEA: North-Eastern Afrotropical; NWA: North-Western Afrotropical; PAF: Pan-African; SAF: Southern African; SEA: SouthEast African; and SWA: South-West Afrotropical.

\section{RESULTS}

The 95 endemic and sub-endemic species of Chaetocnema in the Afrotropical region have the chorotype percentages presented in Fig. 4. Most species have restricted geographical ranges $(66.5 \%)$, with the CAT $(17.7 \%)$, SEA (15.6\%) and MAL (11.5\%) chorotypes being most prevalent. Relatively few species $(11.6 \%)$ have very wide geographical ranges such as AFT (9.4\%) and PAF (2.1\%) chorotypes.

Species of Chaetocnema do not occur in desert areas and rarely occur in dry, open woodland. Fig. 5 shows the number of species (nsp) in relation to latitudinal and longitudinal gradients. Note that the diversity of species north and south of, and equidistant from the Equator is generally quite similar. Few species (6), however, are present in the Sahara desert belt $\left(15^{\circ}-20^{\circ} \mathrm{N}\right)$. Likewise, relatively few species (18) occur between $15^{\circ}-20^{\circ} \mathrm{S}$, which is most likely attributable to the presence there of the Namibian and Angolan desert areas (Namib and northern Kalahari) to the west and a wide belt of dry open woodland to the east; neither of these areas are suitable for species of Chaetocnema. However, this deficit is counterbalanced by numerous species (16) in central-eastern Madagascar (Fig. 5), at the same latitude $\left(15^{\circ}-20^{\circ} \mathrm{S}\right)$. In addition, an examination of the ratio of number of species to $\log$ area $(\mathrm{nsp} / \log \mathrm{A})$ reveals that the highest levels of species richness occur in southern Africa, in latitude ranges $25-30^{\circ} \mathrm{S}(\mathrm{nsp} / \log \mathrm{A}=$ $6.85)$ and $30-35^{\circ} \mathrm{S}(\mathrm{nsp} / \log \mathrm{A}=5.24)$. The number of species is also relatively high in the Equatorial belt $\left(5^{\circ} \mathrm{N}-5^{\circ} \mathrm{S}\right)$. The number of species recorded along the longitudinal gradients (Fig. 5) indicates that species richness levels are 


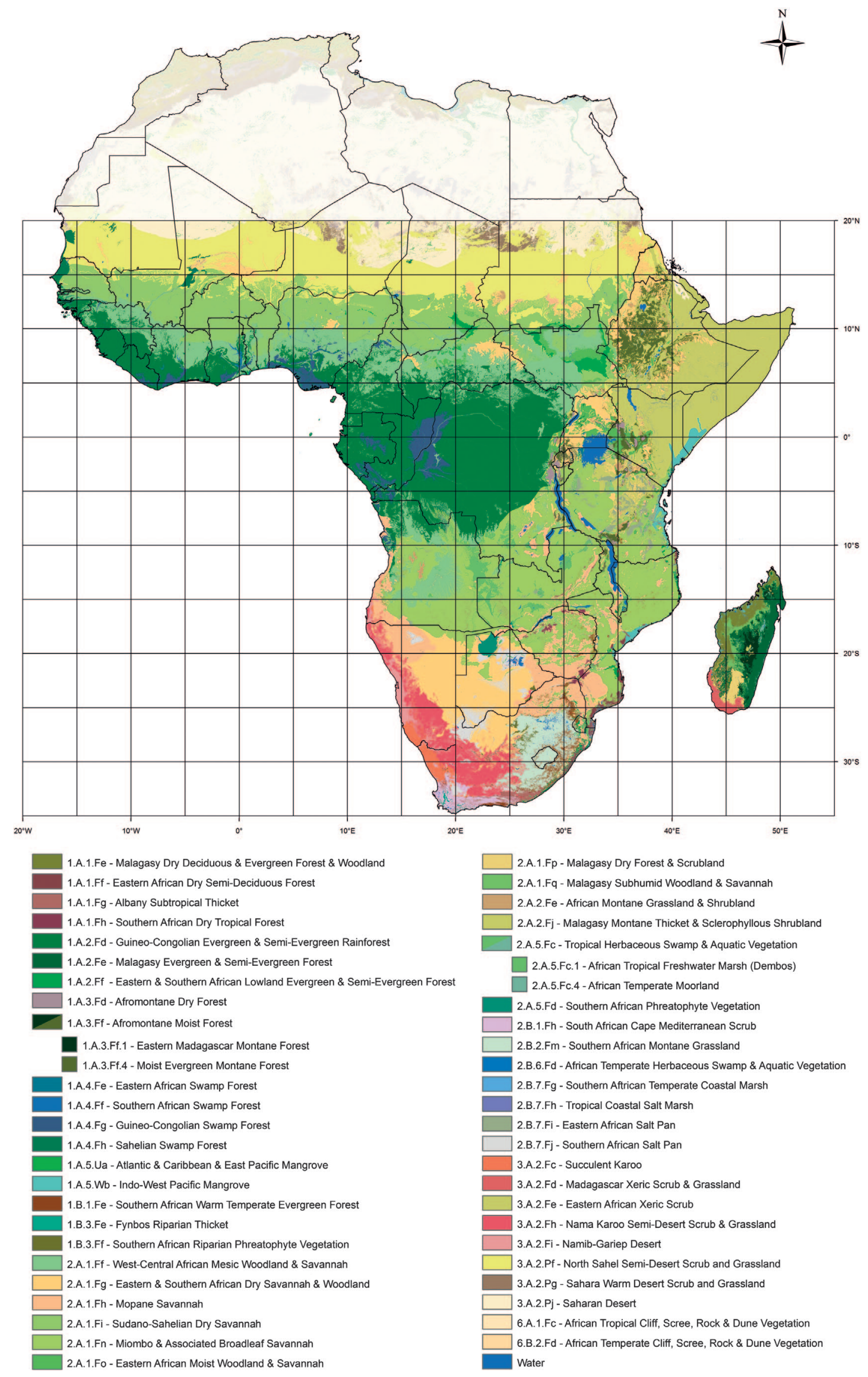

Fig. 1. Distribution of the different types of vegetation in Sub-Saharan Africa and Madagascar as proposed by Sayre et al. (2013) (redrawn from Sayre et al., 2013). 

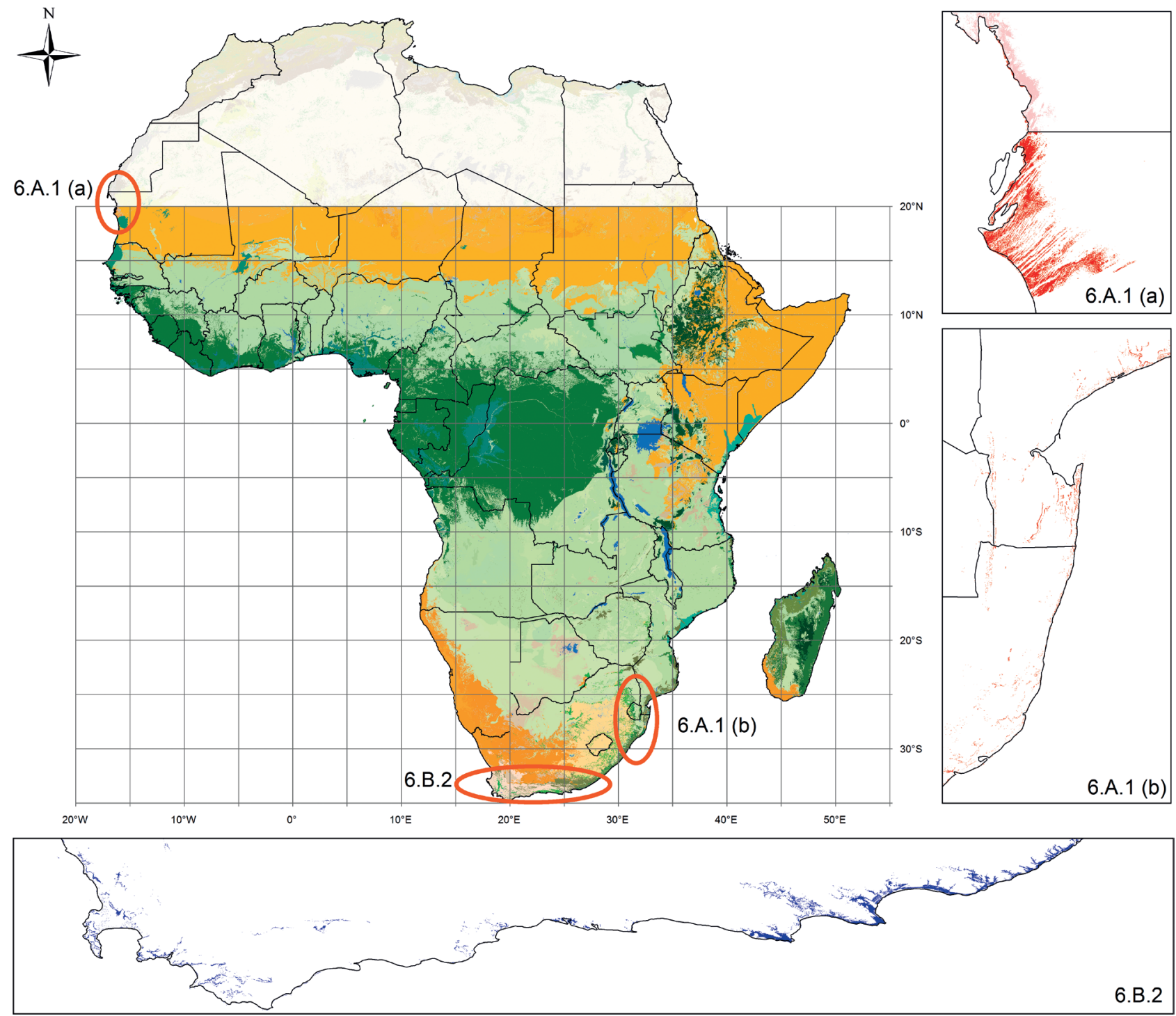

1.A Subclass: Tropical forest Formations

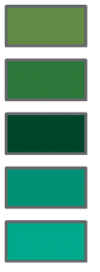

1.A.1 Tropical Seasonally Dry Forest

1.A.2 Tropical Lowland Humid Forest

1.A.3 Tropical Montane Humid Forest

1.A.4 Tropical Flooded \& Swamp Forest

1.A.5 Mangrove

1.B Subclass: Temperate \& Boreal Forest Formations

1.B.1 Warm Temperate Forest

1.B.3 Temperate Flooded \& Swamp Forest

2.A Subclass: Tropical Grassland, Savannah \& Shrubland Formations

2.A.1 Tropical Lowland Grassland, Savannah \& Shrubland

2.A.2 Tropical Montane Grassland \& Shrubland

2.A.5 Tropical Freshwater Marsh, Wet Meadow \& Shrubland
2.B Subclass: Temperate \& Boreal Grassland \& Shrubland Formations

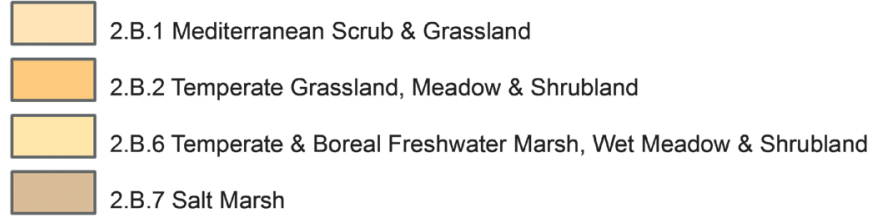

3.A Subclass: Warm Desert \& Semi-Desert Woodland, Scrub \& Grassland Formation

3.A.2 Warm Desert \& Semi-Desert Scrub \& Grassland

6.A Subclass: Tropical Rock Vegetation

Formation

6.A.1 Tropical Cliff, Scree \& Other Rock Vegetation

6.B Subclass: Mediterranean, Temperate \& Boreal Rock Vegetation Formation

6.B.2 Temperate \& Boreal Cliff, Scree \& Other Rock Vegetation

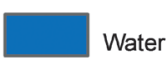

Fig. 2. Distribution of the different vegetation formations in Sub-Saharan Africa and Madagascar as proposed by Sayre et al. (2013) (modified from Sayre et al., 2013). 

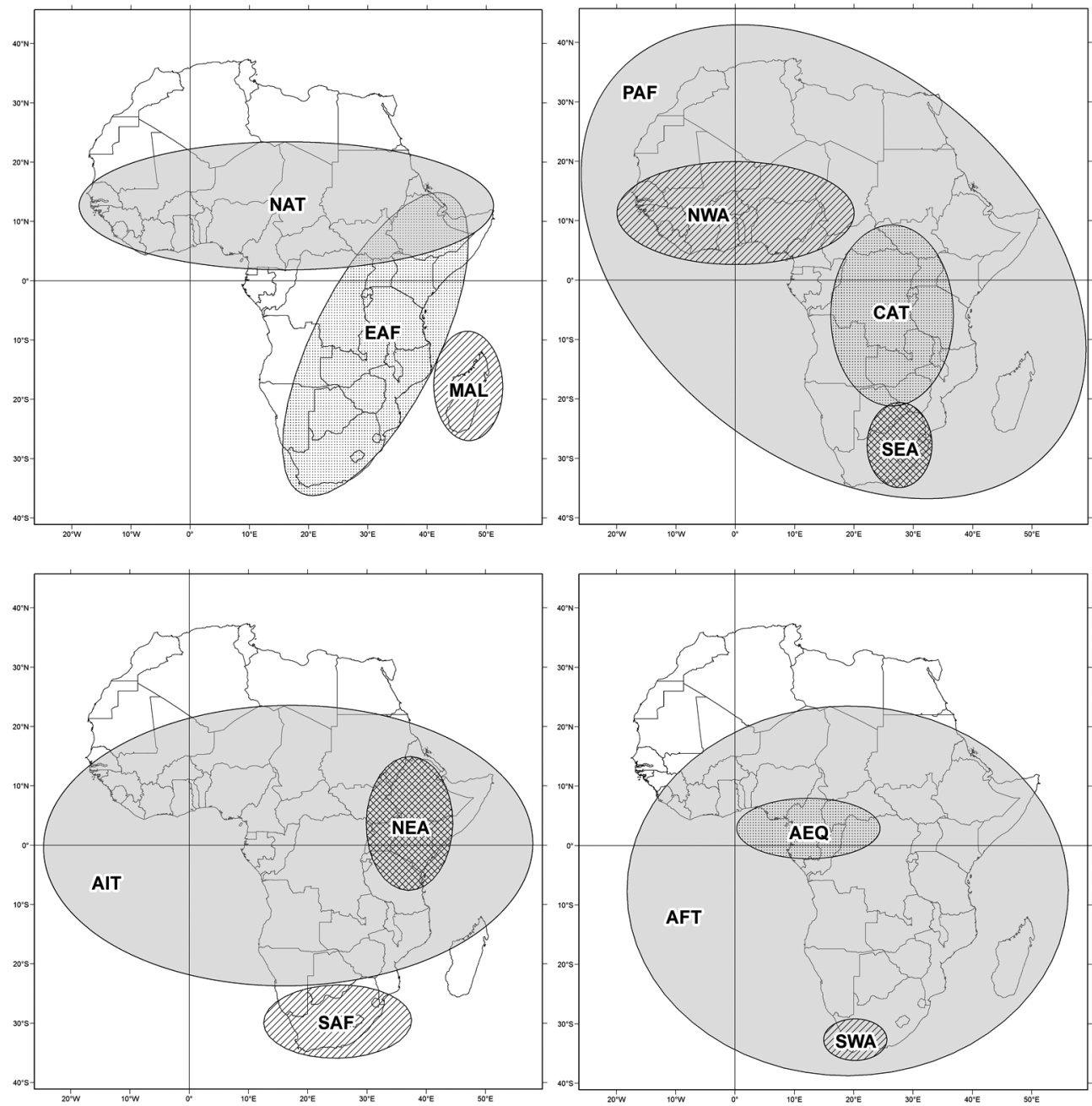

Fig. 3. Different chorotypes of species of Chaetocnema in the Afrotropical region as proposed by Biondi \& D'Alessandro (2006a) (redrawn from Biondi \& D'Alessandro, 2006a): AEQ - Afro-Equatorial; AFT - Afrotropical; AIT - Afro-Intertropical; CAT - Central Afrotropical; EAF - Eastern Afrotropical; MAL - Malagasy; NAT - Northern Afrotropical; NEA - North-Eastern Afrotropical; NWA North-Western Afrotropical; PAF - Pan-African; SAF - Southern African; SEA - South-East African; SWA - South-West Afrotropical.

highest in the longitude range $25-35^{\circ} \mathrm{E}$, where the majority of the important mountainous areas in Sub-Saharan Africa are located (Fig. 5).

Within the Afrotropical region, species of Chaetocnema are generally associated with a limited number of vegetation types. Many of the species $(64.2 \%)$ are associated with fewer than five vegetation divisions, and only $16.8 \%$ exist in more than 10 divisions (Fig. 6). The species occurring in the largest number of vegetation types include $C$. wollastoni (31 divisions), C. pulla (23), C. kibonotensis (22) and C. ljuba (21) (Fig. 7). The correlation between the number of species and the total area of each the type of vegetation considered is moderately high $\left(r=0.65 ; R^{2}=0.42\right)($ Fig. 8).

Some of the vegetation divisions preferred by species of Chaetocnema (Fig. 9) are the following: 2.A.1.Fn (Miombo \& Associated Broadleaf Savannah) with 41 species; 2.A.1.Ff(West-Central African Mesic Woodland \& Savannah) with 38 species; and 2.A.1Fh (Mopane Savannah) with 32 species. These three vegetation divisions, which are all subsets of vegetation formation 2.A.1 (Tropical Lowland Grassland \& Shrubland), show a high percentage $(54.5 \%)$ of species in the Afrotropical region that primarily comprise the EAF (18.2\%), AFT (16.4\%) and AIT (12.7\%) chorotypes, and a significant percentage of species in the CAT $(27.3 \%)$ chorotype.

Vegetation types that are significant for species with restricted geographical ranges (NWA, CAT, NEA, SAF, SEA, SWA and MAL chorotypes) are reported below, in terms of vegetation formations (Sayre et al., 2013) (Fig. 10).

\section{A.1. Tropical Seasonally Dry Forest}

1.A.1.Fg (Albany Subtropical Thicket) $\left(43,020 \mathrm{~km}^{2}\right)$. This vegetation division occurs in semi-arid areas in South Africa (Eastern and Western Cape Province) and is characterized by tall, dense thickets of trees and shrubs (Mucina \& Rutheford, 2006). It includes numerous succulent and thorny species, as well as low thickets dominated by succulents. This type of vegetation covers $2.5 \%$ of the surface area of South Africa (nearly 31,500 $\mathrm{km}^{2}$ ). Certain widespread endemic South African species of Chaetocnema are associated with this vegetation division, with the following chorotypes: SAF (37.5\%: C. darwini, C. natalensis and C. purpurea), SWA (12.5\%: C. chalcea) and SEA (12.5\%: $C$. aluwala). 


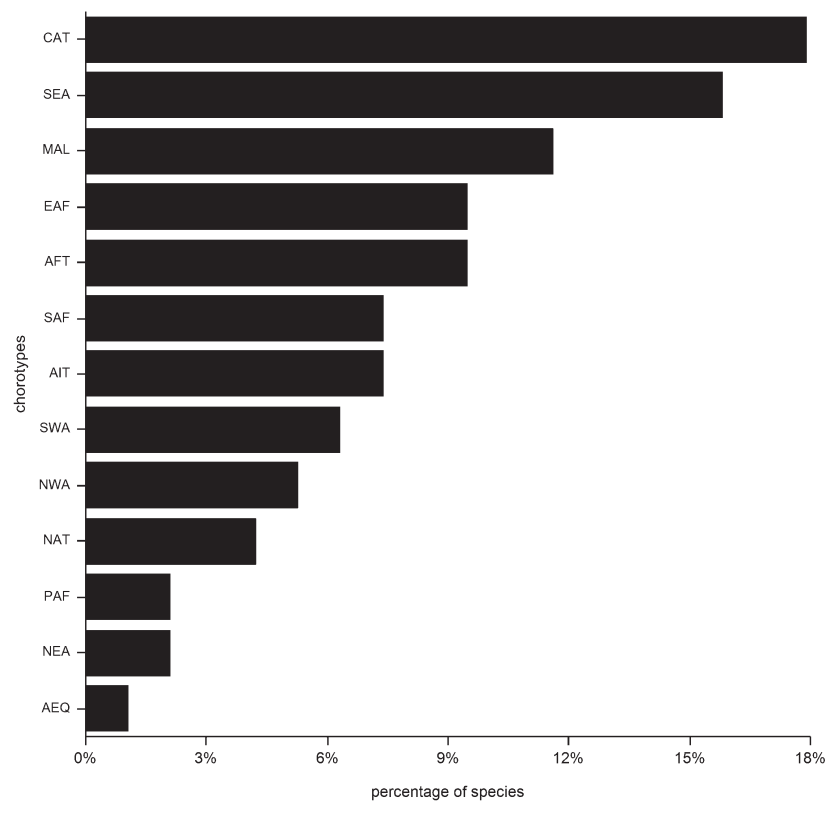

Fig. 4. Percentage of species in each chorotype. Chorotypes: AEQ - Afro-Equatorial; AFT - Afrotropical; AIT - Afro-Intertropical; CAT - Central Afrotropical; EAF - Eastern Afrotropical; MAL - Malagasy; NAT - Northern Afrotropical; NEA North-Eastern Afrotropical; NWA - North-Western Afrotropical; PAF - Pan-African; SAF - Southern African; SEA - South-East African; SWA - South-West Afrotropical.

\section{A.2. Tropical Lowland Humid Forest}

1.A.2.Fd (Guineo-Congolian Evergreen \& Semi-Evergreen Rainforest) $\left(3,078,388 \mathrm{~km}^{2}\right)$. This vegetation division covers a wide area $\left(10^{\circ} \mathrm{N}-10^{\circ} \mathrm{S}\right.$ and $\left.15^{\circ} \mathrm{W}-30^{\circ} \mathrm{E}\right)$ and consists of tall, dense tropical humid forest consisting of several strata. Although some of the canopy species are deciduous, the forest is primarily evergreen or semievergreen. Epiphytes, especially varieties preferring wetter conditions, are abundant. These type of vegetation occurs in Western Africa, extending from coastal regions to the Central Congo basin and also cover transitional areas of woodland formations surrounding the Congo Basin. This vegetation division is particularly significant for species of Chaetocnema occurring in the following chorotypes: NWA (14.3\%: C. compressipes, C. dialloha, C. dubreka, C. mamadoua and C. nahelia), and CAT (14.3\%: C. lopatini, C. maniemaensis, C. obscura, C. impressicollis and C. lufira). Guineo-Congolian Evergreen \& Semi-Evergreen Rainforest is the only vegetation division in the AEQ chorotype (3.0\%: C. cerylonina).

1.A.2.Fe (Malagasy Evergreen \& Semi-Evergreen Forest) $\left(205,865 \mathrm{~km}^{2}\right)$ : this vegetation division includes tropical forests ranging from sea level to an altitude of $1800 \mathrm{~m}$. The Eastern Madagascar Lowland Rainforest is a humid evergreen forest located below an altitude of $800 \mathrm{~m}$ and found along the eastern border of Madagascar. The Eastern Madagascar Subhumid Forest is scattered across several "montane humid zone islands" located throughout the central highlands of Madagascar. It stretches from the northwestern region of Sambirano to north-western areas and includes parts of Amber Mountain in the north. Madagas- can Evergreen Littoral Forest is 5-8 $\mathrm{m}$ high with a closed canopy and often borders coastal lagoons and marshes. This vegetation division contains a significant number of the endemic Madagascan species of Chaetocnema (MAL 53.8\%: C. consobrina, C. hygrophila, C. malgascia, C. orophila, C. pauliani, C. similis and C. vadoni).

\section{A.3. Tropical Montane Humid Forest}

1.A.3.Ff1 (Eastern Madagascar Montane Forest) $\left(52,203 \mathrm{~km}^{2}\right)$. This vegetation macro-group is included in the 1.A.3.Ff (Afromontane Moist Forest) division and includes the Eastern Madagascar tropical montane humid forest that occurs between altitudes of 800 and $1800 \mathrm{~m}$. Eastern Madagascar Montane Forest is more humid and cooler than lowland rainforest. The percentage of Chaetocnema endemism occurring in this vegetation macrogroup is particularly high (MAL 72.3\%: C. basipunctata, C. consobrina, C. cachani, C. coronilla, C. hygrophila, C. orophila and C. vadoni).

\section{B.1. Warm Temperate Forest}

1.B.1.Fe (Southern African Warm Temperate Evergreen Forest) $\left(77,702 \mathrm{~km}^{2}\right)$. This vegetation division includes the Southern Afrotemperate Forest, which includes highlatitude Afrotemperate communities growing at altitudes between 10 and $600 \mathrm{~m}$, though fragmented patches also exist at higher altitudes $(1050-1650 \mathrm{~m})$. The forest structure is multi-layered, tall and particularly prevalent in southern and eastern Africa (KwaZulu-Natal and the Eastern Cape Province), but it is present also in Mpumalanga, Limpopo, Lesotho, Swaziland and other areas in southern Africa (Mucina \& Rutheford, 2006). This vegetation division sustains many endemic South African species of Chaetocne$m a$. The main chorotypes included are: SEA (26.7\%), with C. brincki, C. cinctipennis, C. frereensis, C. longicornis, $C$. mariobiondii, C. subaterrima, C. tongaatensis and C. zulu; SAF (16.7\%), with C. bevinsi, C. capensis, $C$. darwini, $C$. natalensis and C. sudafricana; and SWA (10.0\%), with $C$. audisiana, C. danielssoni and C. tablensis.

\section{B.3. Temperate Flooded \& Swamp Forest}

1.B.3.Fe (Fynbos Riparian Thicket) $\left(6024 \mathrm{~km}^{2}\right)$. Dwarf shrublands divided by rivers and streams, which drain the plains and provide moist conditions suitable for the development of Riparian Thicket. The constituent species are woody shrubs and trees, and the herb layer consists of both grass and dwarf shrubs. This vegetation division occurs mainly in the Western Cape Province and hosts a number of endemic species of Chaetocnema in SAF (42.9\%: $C$. bevinsi, C. capensis and C. darwini) and SWA (42.9\%: $C$. capeneri, C. danielssoni and C. tablensis) chorotypes.

\section{A.1. Tropical Lowland Grassland, Savannah \& Shrubland}

2.A.1.Fn (Miombo \& Associated Broadleaf Savannah) $\left(2,797,195 \mathrm{~km}^{2}\right)$. Miombo woodland is the most widespread tropical type of vegetation on the Central African Plateau (from $5^{\circ}-25^{\circ} \mathrm{S}$ ) and typically grows at altitudes of between 800 and $1200 \mathrm{~m}$. Fires act as part of the functional ecology of these woodlands. Woodland trees are typi- 


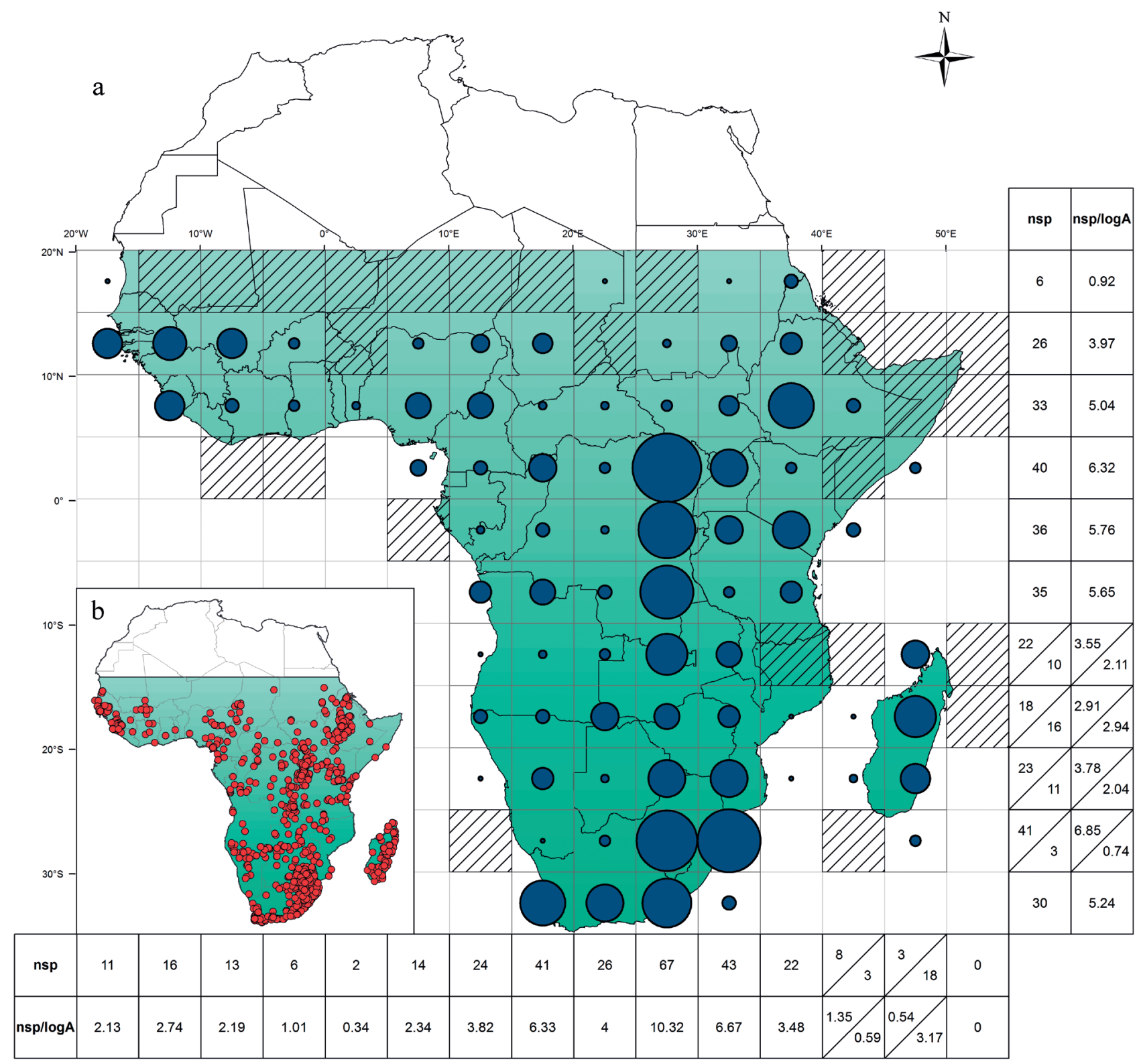

Fig. 5. a - number of species (nsp) and ratio of the number of species per $\log$ area (nsp/logA) along latitudinal and longitudinal gradients. Shading indicates those quadrats not inhabited by any species of Chaetocnema; $\mathrm{b}$ - general distribution of the genus Chaetocnema in Sub-Saharan Africa and Madagascar.

cally 15 to $20 \mathrm{~m}$ tall; understory in wet miombo consists of broadleaf shrubs and a continuous carpet of grass. Dry miombo vegetation is more uniform in structure and less diverse. This broad division is particularly significant for the CAT (31.7\%) chorotype, in which the following species of Chaetocnema mainly occur: $C$. aeneocyanea, $C$. genia, C. kapirensis, C. latipes, C. longipennis, C. lufira, C. maniemaensis, C. mukana, C. muya, C. nigrosericea, $C$. obscura, C. reprehensa and C. rotundicollis.

2.A.1.Fq (Malagasy Subhumid Woodland \& Savannah) $\left(70,371 \mathrm{~km}^{2}\right)$. This division includes seasonal dry woodland communities growing on the Bemaraha Plateau in western Madagascar. Several unique species of plants are included in this vegetation division and endemic species of Chaetocnema are also particularly well represented (MAL 60.0\%: C. basipunctata, C. consobrina and C. pauliani).

\section{A.5. Tropical Freshwater Marsh, Wet Meadow \& Shrubland}

2.A.5.Fc4 (African Temperate Moorland) $\left(18,987 \mathrm{~km}^{2}\right)$. This vegetation macro-group is part of division 2.A.5.Fc (Tropical Herbaceous Swamp \& Aquatic Vegetation). It includes a habitat found in the upland regions of Madagascar in areas of temperate and montane grassland, savannah and shrubland. Temperate Moorland is generally characterized by low-growing vegetation and acidic soils. As in other Malagasy divisions, endemic species of Chaetocnema are well represented (MAL 50.0\%: C. consobrina, C. madagascariensis, C. pauliani and C. vadoni).

\section{B.1. Mediterranean Shrub \& Grassland}

2.B.1.Fh (South African Cape Mediterranean Shrub) $\left(93,650 \mathrm{~km}^{2}\right)$. This vegetation division includes Fynbos, 


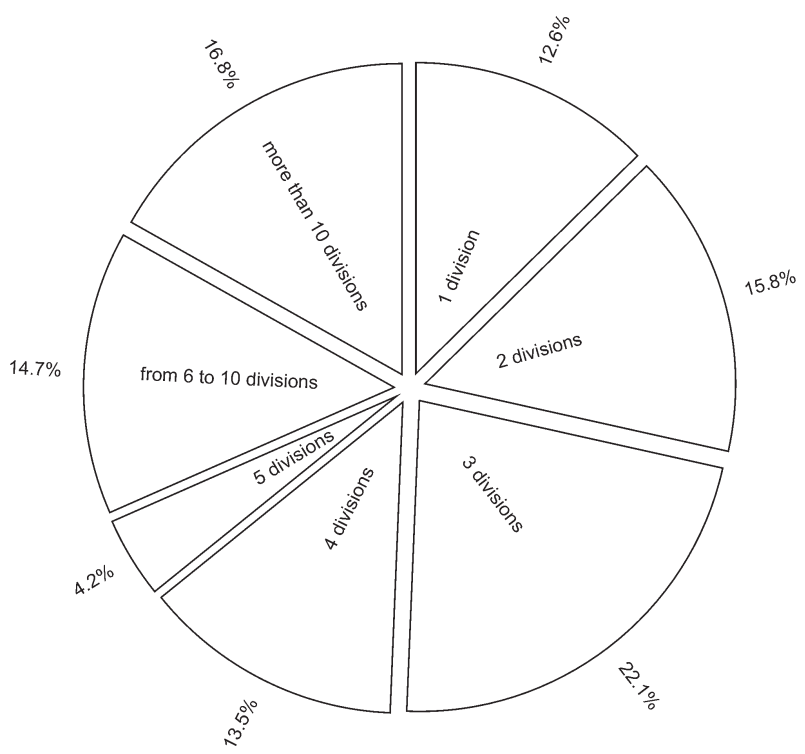

Fig. 6. Percentage of species based on the number of vegetation divisions with which they are associated.

Renosterveld, Strandveld and Cape Thicket ecosystems. The Fynbos ecosystem includes South Africa vegetation consisting of short shrubland or grassland with smallleaved shrubs and Proteaceae elements (Mucina \& Rutheford, 2006). This type of vegetation only occurs in South Africa, and mainly on north-south and east-west mountain chains. It also occurs in wetter valleys in the Cape Fold Belt and the area between the mountainous coast and the Indian Ocean in the south. This division hosts a particularly rich fauna of endemic species of Chaetocnema, particularly in SAF (31.6\%: C. bevinsi, C. capensis, C. darwini, C. natalensis, C. purpurea and C. sudafricana) and SWA (31.6\%: C. audisiana, C. capeneri, C. chalcea, C. convexicollis, C. danielssoni and C. tablensis) chorotypes.

\section{B.2. Temperate Grassland, Meadow \& Shrubland}

2.B.2.Fm (Southern African Montane Grassland) $\left(337,297 \mathrm{~km}^{2}\right)$. This vegetation division includes Drakensberg Grassland, Dry Highveld Grassland, Moist Highveld Grassland, Sub-Escarpment Grassland and Southern Afromontane Grassland. Drakensberg grasslands are mainly associated with the Great Escarpment in the Drakensberg region, which includes Lesotho. Dry high veld grasslands occur on the extensive Central Plateau in South Africa at altitudes between 1200 and $1600 \mathrm{~m}$, whereas moist and mesic high veld grassland occurs in moist highland regions that extend as far as the Northern Escarpment (Mucina \& Rutheford, 2006). This vegetation division hosts a variety of endemic South African species of Chaetocnema, particularly in SEA (30.3\%: C. brincki, C. cinctipennis, C. frereensis, C. longicornis, C. mapumalangaensis, C. phuthaditjhabensis, C. subaterrima, C. tongaatensis, C. turneri and C. zulu) and SAF (18.2\%: C. bevinsi, C. capensis, C. darwini, C. natalensis, C. purpurea and C. sudafricana) chorotypes.

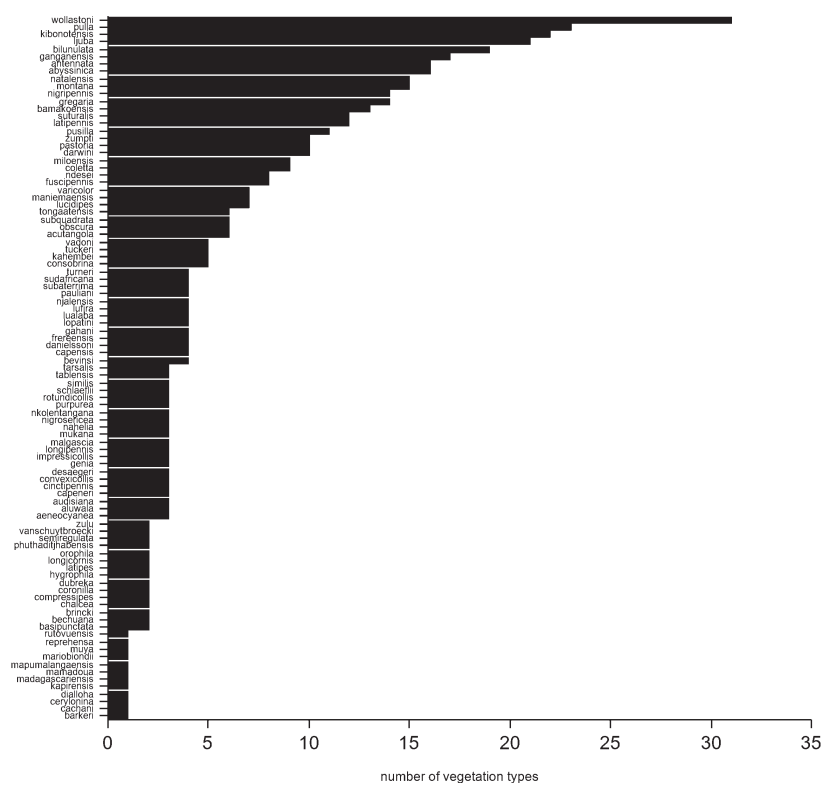

Fig. 7. Number of vegetation types in which each species of Chaetocnema occurs.

\section{A.2. Warm Desert \& Semi-Desert Shrub \& Grassland}

3.A.2.Fc (Succulent Karoo) $\left(96,105 \mathrm{~km}^{2}\right)$. This vegetation division includes the Richtersveld, Namaqualand Hardeveld, Namaqualand Sandveld, Knersvlakte, TransEscarpment Succulent Karoo, Rainshadow Valley Karoo and Sperregebied Succulent Karoo, the vegetation of which is mainly composed of succulents, short shrublands and short grasslands with scattered shrubs. This division occurs at altitudes of between 200 and $1200 \mathrm{~m}$ along the south-western coast of Africa and includes Namaqualand and the south-western corner of Namibia (Mucina \& Rutheford, 2006). Despite the semi-arid characteristics of this vegetation division, it hosts a number of endemic species of South African Chaetocnema (SAF 60.0\%: C. sudafricana and C. tuckeri; SWA 20.0\%: C. capeneri).

\section{B.2. Temperate \& Boreal Cliff, Scree \& Other Rock Vegetation}

6.B.2.Fd (African Temperate Cliff, Scree, Rock \& Dune Vegetation) $\left(2,673 \mathrm{~km}^{2}\right)$. This division includes plant communities growing on sand dunes in South Africa - African Temperate Dune Vegetation. This vegetation is characterized by open shrubland with grasslands growing on dune crests and Acacia trees growing on dune slopes (Mucina $\&$ Rutheford, 2006). Certain endemic South African species of Chaetocnema in two particular chorotypes are significantly associated with this vegetation division (SAF 28.6\%: C. darwini and C. natalensis; SWA 28.6\%: C. audisiana and C. convexicollis).

The results of the cluster analysis (squared Euclidean distance and Ward clustering method) based on presenceabsence data for species of Chaetocnema in the vegetation types examined, are presented in Fig. 11. In the dendrogram (cluster cut off $=0.7$ ) there are five different clusters (A-E): 


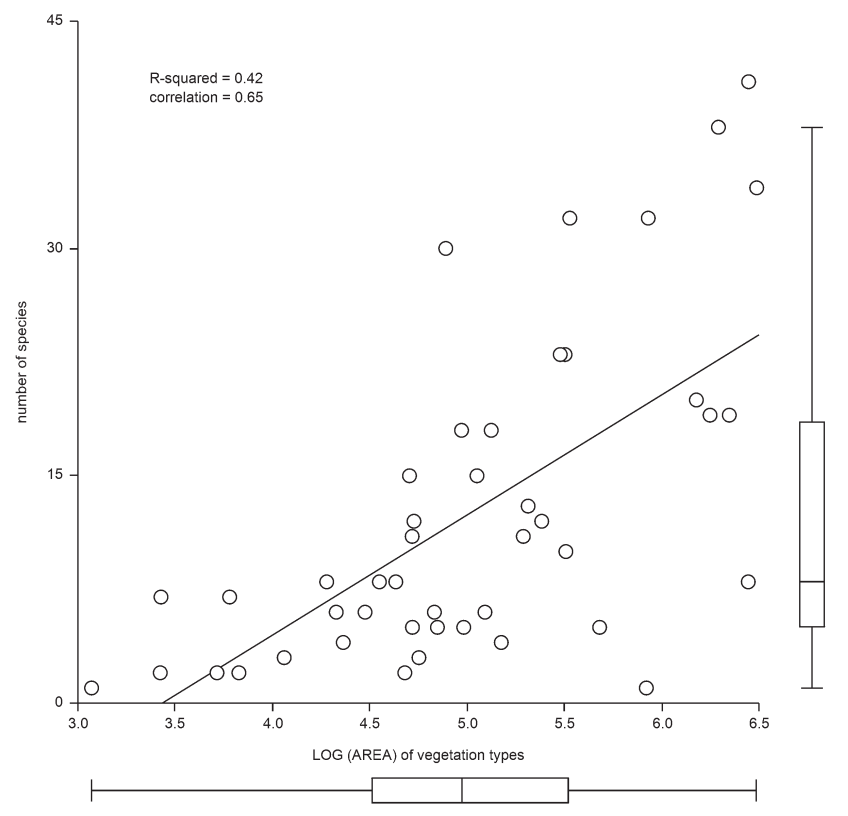

Fig. 8. Regression of the number of species on the area $(\log )$ of vegetation divisions.

Cluster A: includes 24 of the 28 endemic southern African species of Chaetocnema and is represented by chorotypes SEA (45.8\%), SWA (25.32\%) and SAF (20.8\%). The percentage of species associated with Temperate \& Boreal Grassland \& Shrubland $(2 \mathrm{~B}=40.24 \%)$, and with Southern African Montane Grassland (2B2Fm) vegetation divisions is very high; the percentage of species associated with Temperate \& Boreal Forest $(1 \mathrm{~B}=26.8 \%)$, particularly Southern African Warm Temperate Evergreen Forest (1B1Fe), is also significant. Finally, South-African species associated with Tropical Grassland, Savanna \& Shrubland $(2 \mathrm{~A}=11.0 \%)$ and species associated with Tropical Forest $(1 \mathrm{~A}=14.63 \%)$ are represented to a lesser extent in this cluster.

Cluster B: is largely homogenous and includes only endemic Madagascan species. The highest proportion of species is associated with Tropical Forest $(1 \mathrm{~A}=66.7 \%)$, especially with the Malagasy Evergreen \& Semi-Evergreen Forest $(1 \mathrm{~A} 2 \mathrm{Fe})$ vegetation division and the Eastern Madagascar Montane Forest (1.A.3.Ff1) vegetation macro-group. The remaining $33.3 \%$ of the species of Chaetocnema are associated with open environments of Tropical Grassland, Savannah \& Shrubland (2A).

Cluster $\mathrm{C}$ : includes the largest number of species with 36 species of Chaetocnema occurring mainly in the northern and central areas of the Afrotropical region. Sixteen of the 17 species with a CAT chorotype occur in this group $(44.4 \%)$. Cluster $\mathrm{C}$ is the only cluster that includes species with the following chorotypes: NWA (13.9\%), NAT $(11.1 \%)$ and AEQ $(2.8 \%)$. The largest proportion of these species are associated with Tropical Grassland, Savannah \& Shrubland $(2 \mathrm{~A}=56.1 \%)$ and Tropical Forest $(1 \mathrm{~A}$ $=32.71 \%$ ). A significant number of species with a SEA (11.1\%) chorotype are also included. The latter include species mainly associated with Southern African Lowland Evergreen and Semi-Evergreen Forest ( $C$. barkeri), and

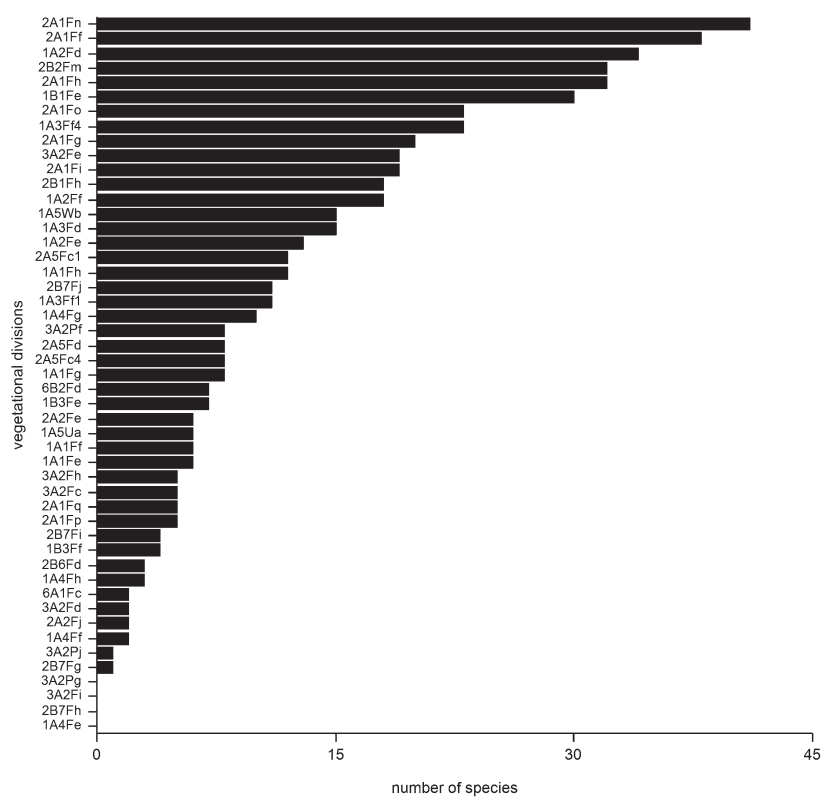

Fig. 9. Number of species of Chaetocnema per vegetation division.

species occurring in forest and/or open environments in southern-eastern Africa with extensions into Zimbabwe, Botswana and/or Zambia (C. aluwala, C. bechuana and C. subquadrata).

Clusters D \& E: these two groups are not significantly different. Cluster D is associated with the highest number of vegetation types, and includes species that are more widespread in the Afrotropical region $(\mathrm{AFT}=57.1 \%$; PAF $=14.50 \% ; \mathrm{EAF}=14.3 \%):$ C. wollastoni, C. pulla, C. $\mathrm{ki}$ bonotensis and C. ljuba (Fig. 7). Although cluster E also includes species that commonly occur across the Afrotropical region, a significant proportion of this cluster is more characteristically "tropical", including species with a AIT (23.5\%) chorotype, such as C. coletta, C. miloensis, $C$. nigripennis and $C$. pastoria, which are all associated with tropical forests and/or savannahs.

\section{CONCLUSIONS}

The geographical ranges of a large percentage (67.3\%) of the endemic and sub-endemic species of Chaetocnema in the Afrotropical region are mainly restricted to Central Africa, southern Africa or Madagascar. Relatively few species $(11.6 \%)$ are widespread in Sub-Saharan Africa and Madagascar. Though this result may in part be attributed to insufficient data, in our view it reflects the true geographical ranges of these species, a phenomenon most likely related to the trend in Chaetocnema towards specialisation and differentiation (Biondi \& D'Alessandro, 2006a).

The number of species along latitudinal and longitudinal gradients reveals that the highest species richness occurs in the Equatorial belt and in southern Africa, especially in montane areas. Endemic species of Chaetocnema are very well represented in Madagascar (61.1\%), which is higher than that recorded for birds (58.4\%) and freshwater fish (59.1\%) (Critical Ecosystems Partnership Fund, 2014 a, b). 


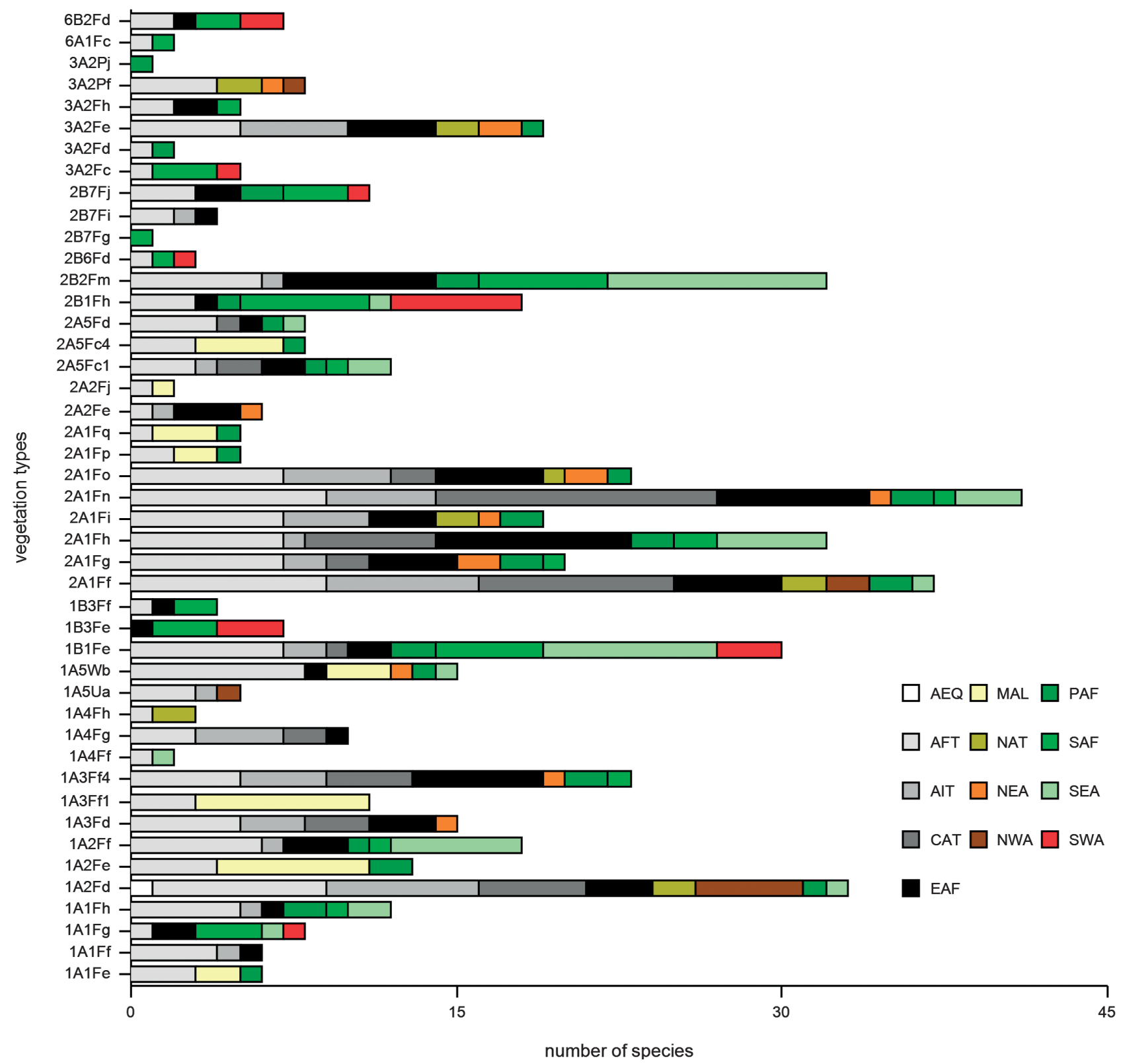

Fig. 10. Number of species per vegetation type and chorotype.

In the Afrotropical region, each species of Chaetocnema is associated with a limited number of vegetation types. The extent of their distribution is significantly and positively correlated with the number of associated vegetation types. For example, species that occur in the largest number of vegetation types, such as $C$. wollastoni, $C$. pulla, $C$. kibonotensis and C. ljuba (Fig. 7), are also the most common and widespread. The correlation between the number of species and the total area for each associated vegetation type is moderately high (Fig. 8).

Chaetocnema species that occur in Sub-Saharan Africa clearly prefer vegetation types that include open grassland environments associated with savannah, and mainly occur in Central and southern Africa. These species do not occur in desert areas and are rarely present in dry open woodlands. However, the highest number of "ecologically characteristic species" occur in forest ecosystems (Fig. 12): tropical lowland and montane humid forests host several endemic species of Chaetocnema, mainly in Madagascar and Western Africa; endemic species are also associated with warm temperate forests in southern Africa. A significant number of endemic species of Chaetocnema are associated with Mediterranean-type vegetation (Fynbos, Renosterveld, Strandveld and Cape Thicket) in SouthWestern Africa.

Notwithstanding the relatively limited extent of the habitats surveyed, a number of the vegetation types considered host a large number of species with high levels of microendemism. This trend is particularly evident in temperate grasslands and forests in montane areas of South Africa, i.e. the Drakensberg region and Mediterranean ecosystems in the Western Cape Province.

Superimposing the general distribution of Afrotropical species of Chaetocnema on the biodiversity hotspots 


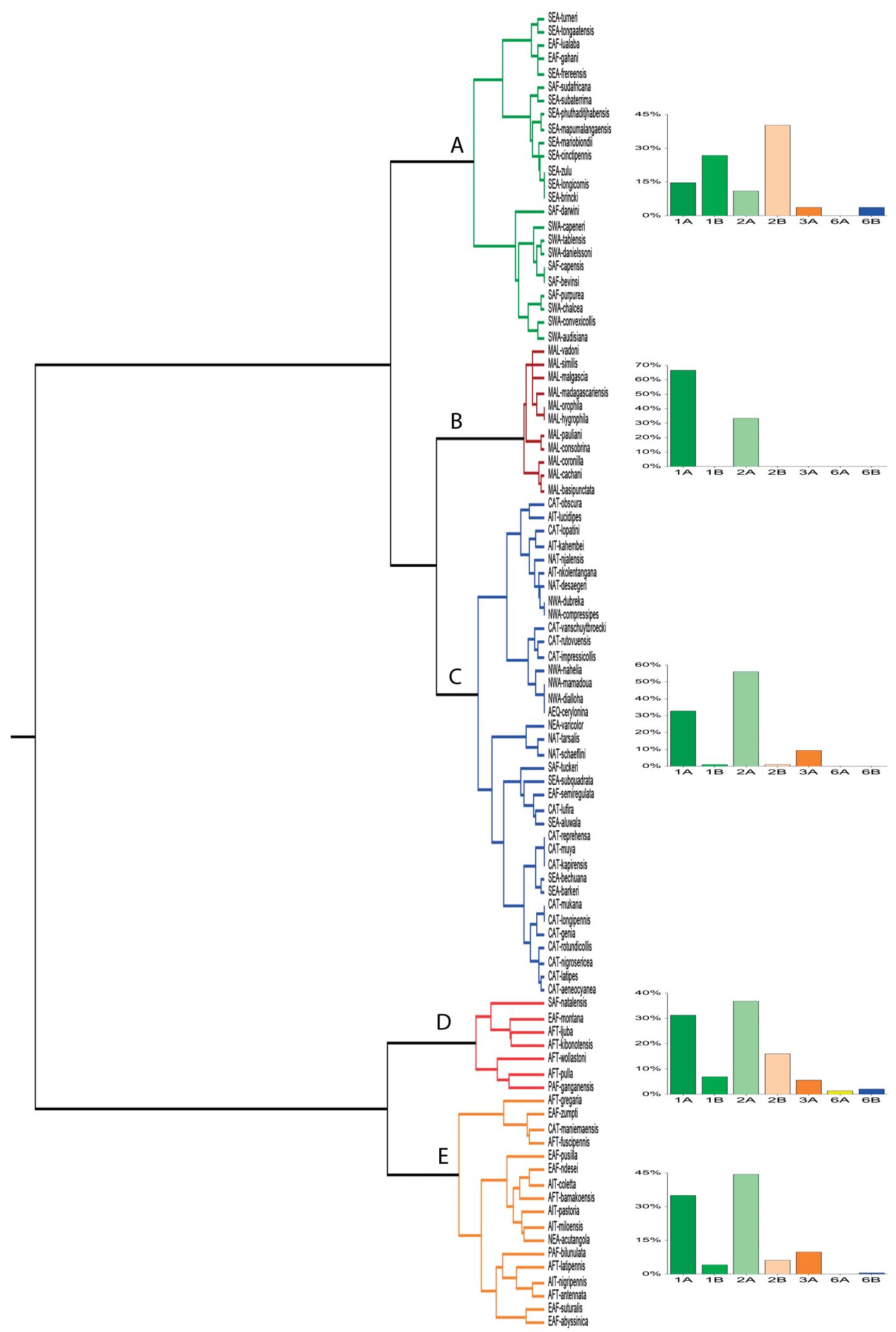

Fig. 11. Dendrogram resulting from cluster analysis based Squared Euclidean Distance and Ward Clustering Method. A-E indicate the five different clusters identified by this analysis (cluster cut off $=0.7$ ) (see text). Histograms indicate the percentages of species per cluster for each vegetation sub-class. Chorotypes: AEQ - Afro-Equatorial; AFT - Afrotropical; AIT - Afro-Intertropical; CAT - Central Afrotropical; EAF - Eastern Afrotropical; MAL - Malagasy; NAT - Northern Afrotropical; NEA - North-Eastern Afrotropical; NWA - North-Western Afrotropical; PAF - Pan-African; SAF - Southern African; SEA - South-East African; SWA - South-West Afrotropical. Vegetation subclasses: 1A - Tropical Forest; 1B - Temperate \& Boreal Forest; 2A - Tropical Grassland, Savannah \& Shrubland; 2B - Temperate \& Boreal Grassland \& Shrubland; 3A - Warm Desert \& Semi-Desert Woodland, Shrub \& Grassland; 6A - Tropical Rock Vegetation; 6B - Mediterranean, Temperate \& Boreal Rock Vegetation. 

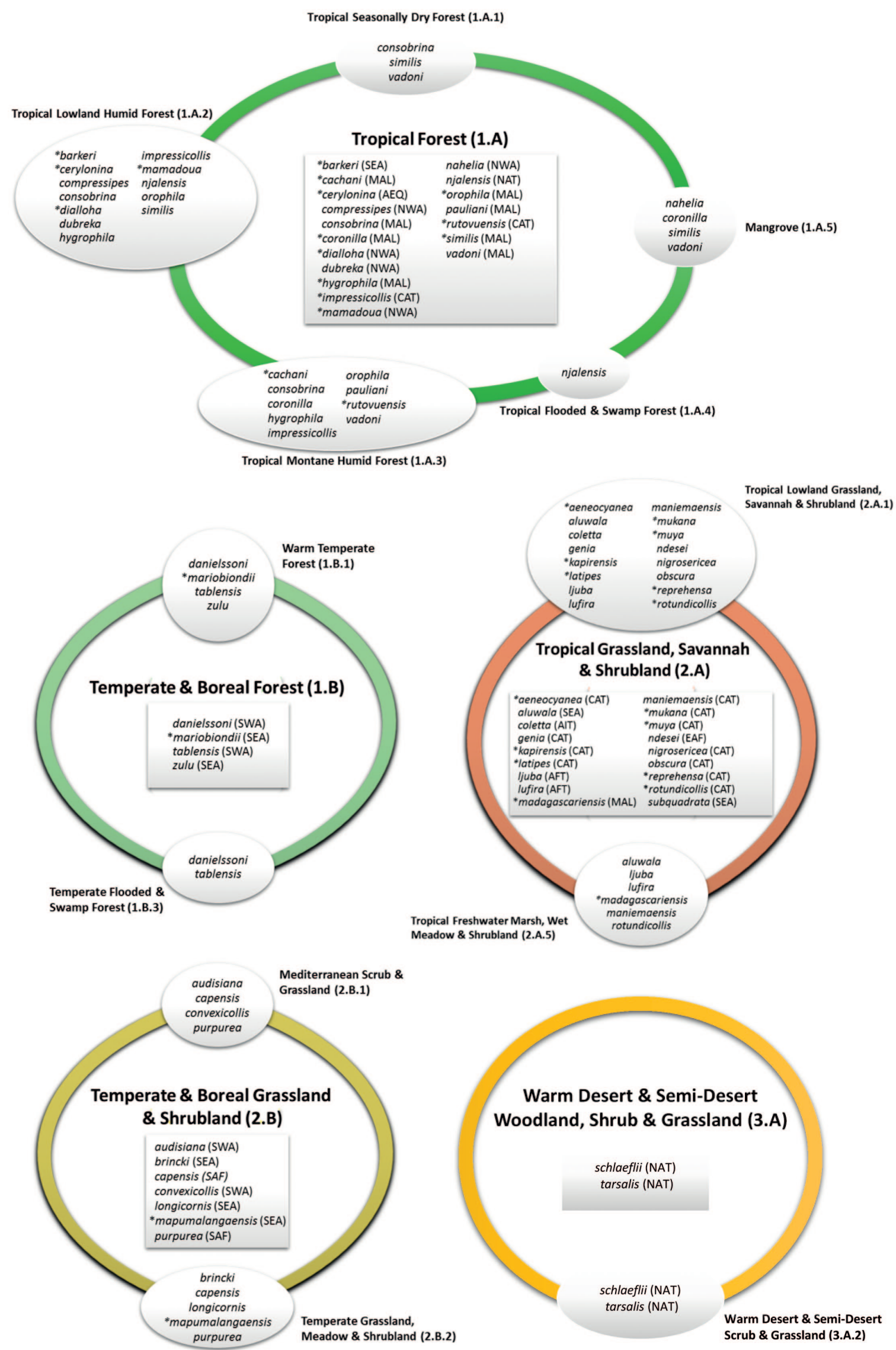

Fig. 12. "Ecologically characteristic species" recorded in the different sub-classes and formations of vegetation. Exclusive species marked by an asterisk, other species are included when at least $70 \%$ of their total occurrences lie in the respective sub-class or formation of vegetation. 


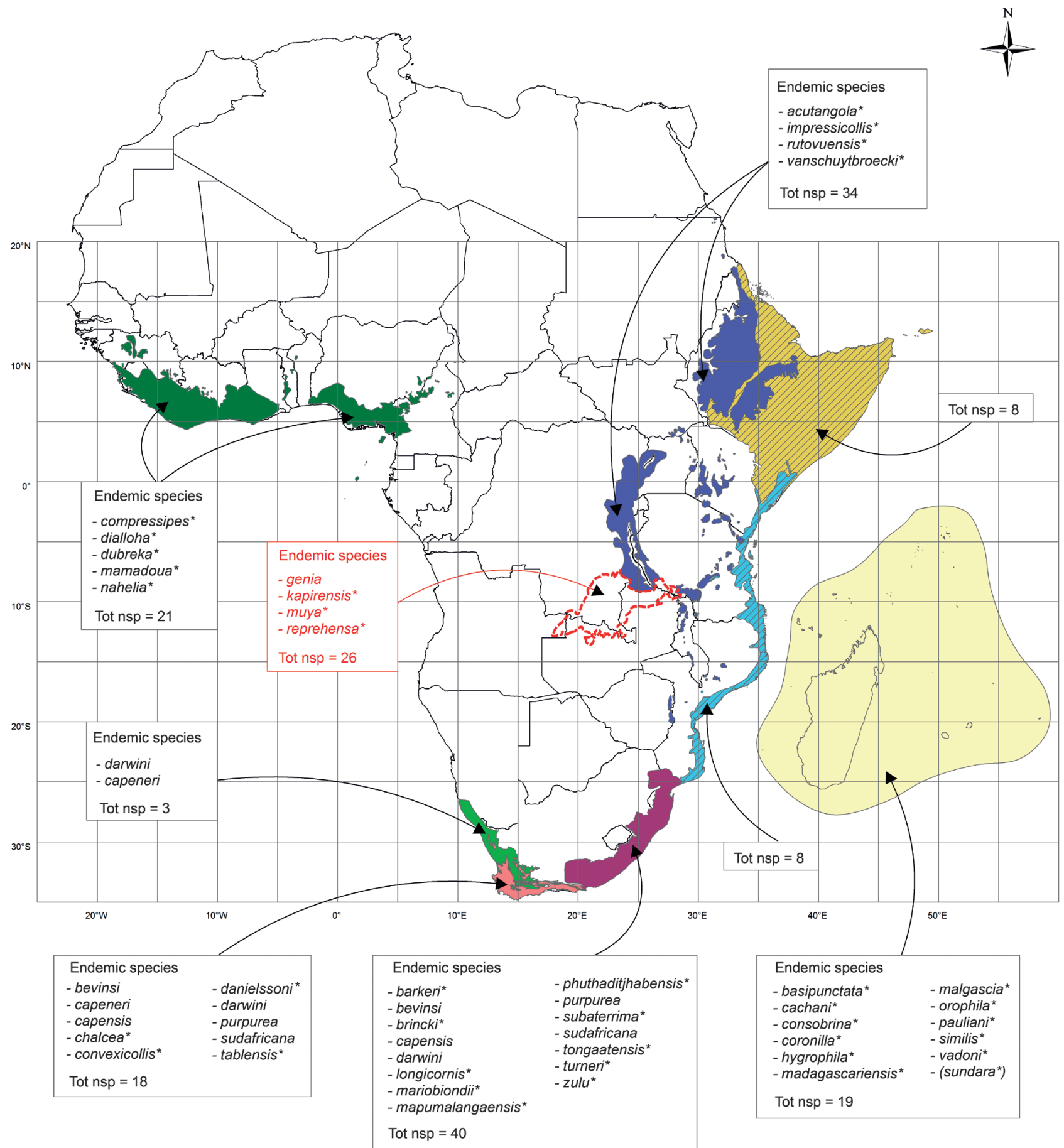

Cape Floristic Region (Hotspot n. 3)

Madagascar and the Indian Ocean Islands (Hotspot n. 17)

Coastal Forests of Eastern Africa (Hotspot n. 8)

Eastern Afromontane (Hotspot n. 10)

Guinean Forests of West Africa (Hotspot n. 11)

Horn of Africa (Hotspot n. 13)

Maputaland-Pondoland-Albany (Hotspot n. 19)

Succulent Karoo (Hotspot n. 29)

Proposed extension for the Hotspot n.10 (Eastern Afromontane)

* Strictly endemic species

Fig. 13. Endemic and sub-endemic species of Chaetocnema occurring in biodiversity hotspots in Sub-Saharan Africa and Madagascar, as reported on the Conservation International website (see Critical Ecosystems Partnership Fund, 2014b) Tot nsp = the total number of species of Chaetocnema recorded in a particular region.

identified in Sub-Saharan Africa and Madagascar (Critical Ecosystem Partnership Fund, 2014b), reveals that endemic species of Chaetocnema occur in as many as six of the eight hotspots (Fig. 13): 
Cape Floristic Region Biodiversity Hotspot is home to ten endemic species of Chaetocnema, four of which only occur in this region (chalcea, convexicollis, danielssoni and tablensis) with a $16.7 \%$ level of endemism. Two of the species also occur in the Succulent Karoo Biodiversity Hotspot (darwini and capeneri) and five in the Maputaland-Pondoland-Albany Biodiversity Hotspot (bevinsi, capensis, darwini, purpurea and sudafricana).

Eastern Afromontane Biodiversity Hotspot: four endemic species of Chaetocnema occur here (acutangola, impressicollis, rutovuensis and vanschuytbroecki), with an $11.8 \%$ level of endemism. However, in this case the distribution of Chaetocnema suggests a potential extension of this hotspot to include the Katanga and Mitumba Mountains. Four endemic and sub-endemic species of Chaetocnema occur in this area (genia, kapirensis, muya and reprehensa), all of which are associated with the 2.A.1 vegetation division [Tropical Lowland Grassland, Savannah \& Shrubland (2.A.1)].

Guinean Forests of West Africa Biodiversity Hotspot: five endemic species occur in this hotspot (compressipes, dialloha, dubreka, mamadoua and nahelia) with a $23.8 \%$ level of endemism.

Madagascar and the Indian Ocean Islands Biodiversity Hotspot: 12 endemic species of Chaetocnema occur here (basipunctata, cachani, consobrina coronilla, hygrophila, madagascariensis, malgascia, orophila, pauliani, similis and vadoni on Madagascar, and C. sundara Maulik on the Seychelles Islands), with a very high $63.2 \%$ level of endemism.

Maputaland-Pondoland-Albany Region Biodiversity Hotspot: 15 endemic South African species occur here, ten of which are endemics with a $25.0 \%$ level of endemism.

Succulent Karoo Biodiversity Hotspot: two endemic species (darwini and capeneri) occur here however, they also occur in the Cape Floristic Region Biodiversity Hotspot.

No endemic species of Chaetocnema are recorded in either the Coastal Forests of Eastern Africa or the Horn of Africa Biodiversity Hotspots.

The ecological valence and limited geographical distributions of several of the Chaetocnema species studied indicate that this flea beetle genus can be used to characterize both the biogeography and ecology of the Afrotropical region (Fig. 12).

ACKNOWLEDGEMENTS. We are grateful to colleagues who enabled us to study material in their respective institutions or private collections. A special thanks to E. Grobbelaar (Pretoria) for his suggestions and valuable collaboration.

\section{REFERENCES}

Bechyné J. 1948: De novis speciebus Halticidarum Madagascariensium (Col. Phytophaga.). - Čas. Čs. Spol. Entomol. 45: $3-11$.

Bechyné J. 1954: Reise des Herrn G. Frey in Süd-Afrika: Alticinae (Col. Phytoph.). - Entomol. Arb. Mus. G. Frey 5: 675685.

Bechyné J. 1955a: Contributions à l'étude de la faune entomologique du Ruanda-Urundi (Mission P. Basilewsky 1953).
LXIV. Coleoptera Chrysomelidae Chrysomelinae et Alticinae. - Ann. Mus. R. Congo Belge (Sci. Zool.) 40: 204-230.

BeChyNé J. 1955b: Über die westafrikanischen Alticiden (Col. Phyt.). — Entomol. Arb. Mus. G. Frey 6: 486-568.

BeCHYNÉ J. 1959a: Observations sur les Alticides recueillis au Congo belge par M.A. Collart (Coleoptera, Phytophaga). Bull. Inst. R. Sci. Nat. Belg. 35: 1-36.

BeChyné J. 1959b: Coleoptera: Chrysomelidae II. In Hanström B., Brinck P. \& Rudebeck B. (eds): South African Animal Life, Results of the Lund University Expedition in 1950-1951. Vol. VI, chapter XII. Almquist \& Wiksell, Stockholm, pp. 227-238.

Bechyné J. 1960a: Notes sur les Alticides africains des collections de 1'Institut royal des Sciences naturelles de Belgique (Coleoptera, Phytophaga). - Bull. Inst. R. Sci. Nat. Belg. 36: $1-32$.

Bechyné J. 1960b: Alticidae (Coleoptera, Phytophaga). Exploration du Parc National de l'Upemba. Mission G.F. de Witte (1946-1949). Institut Parcs Nationaux du Congo Belge, Bruxelles, fasc. no. 59, pp. 39-114.

BeChyné J. 1964: Notizen zu den madagassischen Chrysomeloidea (Col. Phytophaga). - Mitt. Münch. Entomol. Ges. 54: 68-161.

BeChyNÉ J. 1968: Contribution à la faune du Congo (Brazzaville). Mission A. Villiers et A. Descarpentries. - Bull. Inst. Fond. Afr. Noire (ser. A4) 30: 1687-1728.

BIONDI M. 2001: Revision of the species of Chaetocnema from Madagascar (Coleoptera: Chrysomelidae: Alticinae). — Eur. J. Entomol. 98: 233-248.

Biond M. 2002a: Chaetocnema Stephens and related genera: a systematic revision, with description of a new genus from the Indian Ocean (Seychelles) (Coleoptera, Chrysomelidae). Ital. J. Zool. 69: 22-33.

Biondi M. 2002b: Checklist of the Afrotropical species of the genus Chaetocnema Stephens (Coleoptera, Chrysomelidae: Alticinae): synonymies and geographical distributions. - Afr. Entomol. 10: 265-284.

Biondi M. \& D'Alessandro P. 2005: Chaetocnema conducta (Motschulsky) and its kindred species in the Afrotropical Region, with description of C. lopatini, a new species from Central Africa (Coleoptera, Chrysomelidae, Alticinae). In Konstantinov A., Tishechin A. \& Penev L. (eds): Contributions to Systematics and Biology of Beetles. Papers Celebrating the $80^{\text {th }}$ Birthday of Igor Konstantinovich Lopatin. Pensoft, Sofia, pp. 3-16.

Biondi M. \& D'Alessandro P. 2006a: Biogeographical analysis of the flea beetle genus Chaetocnema in the Afrotropical Region: distribution patterns and areas of endemism. - J. Biogeogr. 33: 720-730.

Biondi M. \& D'Alessandro P. 2006b: Revision of the Chaetocnema gahani species-group from South Africa with description of four new species (Coleoptera, Chrysomelidae). - Ann. Soc. Entomol. Fr. (N. S.) 42: 183-196.

Biondi M. \& D'Alessandro P. 2008: Revision of the Chaetocnema pulla species-group from the Afrotropical region with description of a new species from Central Africa (Coleoptera: Chrysomelidae). In Jolivet P., Santiago-Blay J. \& Schmitt M. (eds): Research on Chrysomelidae. Vol. 1. Brill, Leiden, pp. 265-285.

Biondi M. \& D'Alessandro P. 2012: The Afrotropical flea beetle genera: a key to their identification, updated catalogue and biogeographical analysis (Coleoptera, Chrysomelidae, Galerucinae, Alticini). - Zookeys 252: 1-158.

Biondi M. \& De Nardis G. 2000: The Chaetocnema of the longicornis species-group: systematics and geographic distribution 
(Coleoptera: Chrysomelidae, Alticinae). - Insects Syst. Evol. 32: $27-42$.

Bryant G.E. 1926: New species of Phytophaga (Col.). - Ann. Mag. Nat. Hist. (Ser. 9) 17: 403-410.

Bryant G.E. 1928: Revision of the African species of Chaetocnema (Col., Halticidae). - Ann. Mag. Nat. Hist. (Ser. 10) 2: 393-407.

BRYANT G.E. 1948: New species of Chrysomelidae (Halticinae) from East Africa. - Ann. Mag. Nat. Hist. (Ser. 12) 1: 145-171.

Bryant G.E. 1959a: Coleoptera: Chrysomelidae I. In Hanström B., Brinck P. \& Rudebeck B. (eds): South African Animal Life, Results of the Lund University Expedition in 1950-1951. Vol. VI, chapter XII. Almquist \& Wiksell, Stockholm, pp. 194-226.

BRYANT G.E. 1959b: Coleoptera: Chrysomelidae. In: Ruwenzori Expedition 1952. Vol. II, No. 1. British Museum (Natural History), London, pp. 1-15.

Bryant G.E. 1960: Mission zoologique de l'I.R.S.A.C. en Afrique orientale (P. Basilewsky et N. Leleup, 1957). XXI. Coleoptera Chrysomelidae. - Ann. Mus. R. Congo Belge (Sci. Zool.) 81: 342-368.

Critical Ecosystems Partnership Fund 2014a: Ecosystem Profile. Madagascar and Indian Ocean Islands. http://www.cepf net/SiteCollectionDocuments/madagascar/EcosystemProfile Madagascar_EN.pdf (access 15/06/2014).

Critical Ecosystems Partnership Fund 2014b: Regions. http:// www.cepf.net/where_we_work/regions/africa/Pages/default. aspx (access 15/06/2014).

Elith J., Graham C.H., Anderson R.P., Dudík M., Ferrier S., Guisan A., Hijmans R.J., Huettmann F., Leathwick J.R., Lehmann A., Li J., Lohmann L.G., Loiselle B.A., Manion G., Moritz C., Nakamura M., Nakazawa Y., Peterson A.T., Phillips S J., Richardson K.S., Scachetti-Pereira R., Schapire R.E., Soberón J., Williams S., Wisz M.S. \& Zimmermann N.E. 2006: Novel methods improve prediction of species' distributions from occurrence data. - Ecography 29: 129-151.

FERRIER S. 2002: Mapping spatial pattern in biodiversity for regional conservation planning: where to from here? - Syst. Biol. 51: 331-363.

Franklin J. 2009: Mapping Species Distributions: Spatial Inference and Prediction. Cambridge University Press, Cambridge, $336 \mathrm{pp}$.

FunK V. \& Richardson K. 2002: Systematic data in biodiversity studies: use it or lose it. - Syst. Biol. 51: 303-316.

HinTZE J. 2013: NCSS 9. NCSS, LLC. Kaysville, UT. www.ncss. com.

Jolivet P. \& Hawkeswood T.J. 1995: Host-Plants of Chrysomelidae of the World. An Essay about the Relationships between the Leaf-Beetles and their Food-Plants. Backhuys, Leiden, 281 pp.

Kent M. 2006: Numerical classification and ordination in biogeography. - Progr. Phys. Geogr. 30: 399-408.

Konstantinov A.S., Baselga A., Grebennikov V.V., Prena J. \& Lingafelter S.W. 2011: Revision of the Palearctic Chaetocnema species (Coleoptera: Chrysomelidae: Galerucinae: Alticini). Pensoft, Sofia-Moscow, 363 pp.

LAWTON J.H. 1983: Plant architecture and the diversity of phytophagous insects. - Annu. Rev. Entomol. 28: 23-39.

Legendre P. \& De CÁceres M. 2013: Beta diversity as the variance of community data: dissimilarity coefficients and partitioning. - Ecol. Lett. 16: 951-963.

Löbl I. \& Smetana A. 2010: Catalogue of Palaearctic Coleoptera. Vol. 6. Chrysomeloidea. Apollo Books, Stenstrup, 924 pp.

LoUREnÇO F., LoBo V. \& BAÇ̃̃o F. 2004: Binary based similarity measures for categorical data and their applications in self-organizing maps. In: Proceedings of JOCLAD 2004, XI Jornadas de Classificação e Análise de Dados, Lisbon, 1-3 April 2004. Lisabon, pp. 1-8.

Martín J. \& GurRea P. 1999: Áreas de especiación en España y Portugal. - Bol. Asoc. Esp. Entomol. 23: 83-103.

McCoy E.D. \& Bell S.S. 1991: Habitat structure: the evolution and diversification of a complex topic. In Bell S.S., McCoy E.D. \& Mushinsky H.R. (eds): Habitat Structure: The Physical Arrangement of Objects in Space. Chapman \& Hall, London, pp. 3-27.

Mucina L. \& Rutheford M.C. (eds) 2006: The Vegetation of South Africa, Lesotho and Swaziland. Strelitzia 19 (Reprint 2011). South African National Biodiversity Institute, Pretoria, $808 \mathrm{pp}$.

Olivero J., Real R. \& MÁrquez A.L. 2011: Fuzzy chorotypes as a conceptual tool to improve insight into biogeographic patterns. - Syst. Biol. 60: 645-660.

Rushton S.P., Ormerod S.J. \& Kerby G. 2004: New paradigms for modelling species distributions? - J. Appl. Ecol. 41: 193200.

Sayre R., Comer P., Hak J., Josse C., Bow J., Warner H., Larwanou M., Kelbessa E., Bekele T., Kehl H., Amena R., Andriamasimanana R., Ba T., Benson L., Boucher T., Brown M., Cress J., Dassering O., Friesen B., Gachathi F., Houcine S., Keita M., Khamala E., Marangu D., Mokua F., Morou B., Mucina L., Mugisha S., Mwavu E., Rutherford M., Sanou P., Syampungani S., Tomor B., Vall A., Vande Weghe J., Wangu E. \& Waruingi L. 2013: A New Map of Standardized Terrestrial Ecosystems of Africa. Association of American Geographers, Washington, DC.

Scherer G. 1959: Die Alticiden-Ausbeute der Expedition des Museums G. Frey nach Nigeria-Kamerun 1955/56 (Col. Phytoph.). - Entomol. Arb. Mus. G. Frey 10: 177-265.

Scherer G. 1961a: Liste der von Herrn P. Renaud im Tchad-Gebiet gesammelten Alticiden (Coleoptera Chrysomelidae Alticinae). - Rev. Zool. Bot. Afr. 64: 172-174.

SCHERER G. 1961b: Bestimmungsschlüssel der Alticinen-Genera Afrikas (Col. Phytoph.). - Entomol. Arb. Mus. G. Frey 12: 251-289.

SCHERER G. 1962a: Beitrag zur Kenntnis der Alticiden-Fauna Zentral-Afrikas (Coleoptera Chrysomelidae Alticinae). Ann. Mus. R. Afr. Centr. (Sci. Zool.) 113: 1-82.

Scherer G. 1962b: Alticinae (Coleoptera Phytophaga). Fam. Chrysomelidae. In: Exploration du Parc National de la Garamba, Mission H. De Saeger en Collaboration avec Baert P, Demoulin G, Denisoff I, Martin J, Micha M, Noirfalise A, Schoemaker P, Troupin G, Verschuren J (1949-1952), Fasc. 31. Institut des Parcs Nationaux du Congo et du Rwanda, Bruxelles, pp. 3-86.

SCHERER G. 1963: Beitrag zur Kenntnis des Alticidenfauna Afrikas (Coleoptera, Chrysomelidae, Alticinae). - Entomol. Arb. Mus. G. Frey 14: 648-684.

SCHERER G. 1969: Contributions à la connaissance de la faune entomologique de la Côte-D'Ivoire (J. Decelle, 1961-1964). XLIII. Coleoptera Chrysomelidae Alticinae. - Ann. Mus. R. Afr. Centr. (Sci. Zool.) 175: 365-371.

SCHERER G. 1970: Beitrag zur Kenntnis der Alticinae Afrikas (Coleoptera: Chrysomelidae: Alticinae). - Entomol. Arb. Mus. G. Frey 21: 298-304.

SCHERER G. 1972: Coleoptera aus Nordostafrika. Chrysomelidae: Alticinae. - Notul. Entomol. 52: 1-17.

SCHERER G. 1978: Missione 1965 del professor Giuseppe Scortecci nello Yemen (Arabia Meridionale). Coleoptera Chrysomelidae: Alticinae. - Atti Soc. Ital. Sci. Nat. Mus. Civ. Stor. Nat. Milano 119: 264-266. 
SCLATER P. 1858: On the general distribution of the members of the class Aves. - J. Linn. Soc. Zool. Lond. 2: 130-145.

Tews J., Brose U., Grimm V., Tielbörger K., Wichmann M.C., Schwager M. \& Jeltsch F. 2004: Animal species diversity driven by habitat heterogeneity/diversity: the importance of keystone structures. - J. Biogeogr. 31: 79-92.

Vigna Taglianti A., Audisio P.A., Belfiore C., Biondi M., Bologna M.A., Carpaneto G.M., De Biase A., De Felici S., Piattella E., Racheli T., Zapparoli M. \& Zoia S. 1992: Riflessioni di gruppo sui corotipi fondamentali della fauna $\mathrm{W}$-paleartica ed in particolare italiana. - Biogeographia 16: 159-179.
Vigna Taglianti A., Audisio P.A., Biondi M., Bologna M.A., Carpaneto G.M., De Biase A., Fattorini S., Piattella E., Sindaco R., Venchi A. \& Zapparoli M. 1999: A proposal for a chorotype classification of the Near East Fauna, in the framework of the Western Palearctic region. - Biogeographia 20: 31-59.

WARD J.H. 1963: Hierarchical grouping to optimize an objective function. - Am. Stat. Assoc. J. 58: 236-244.

White R.E. 1996: A revision of the genus Chaetocnema of America north of Mexico (Coleoptera: Chrysomelidae). - Contr. Am. Entomol. Inst. 29: 3-158.

Received August 26, 2014; revised and accepted November 27, 2014 Prepublished online February 9, 2015 